\title{
The Costs of Using Crop Residues in Direct Combustion Applications
}

Silvio Flaim

David Urban
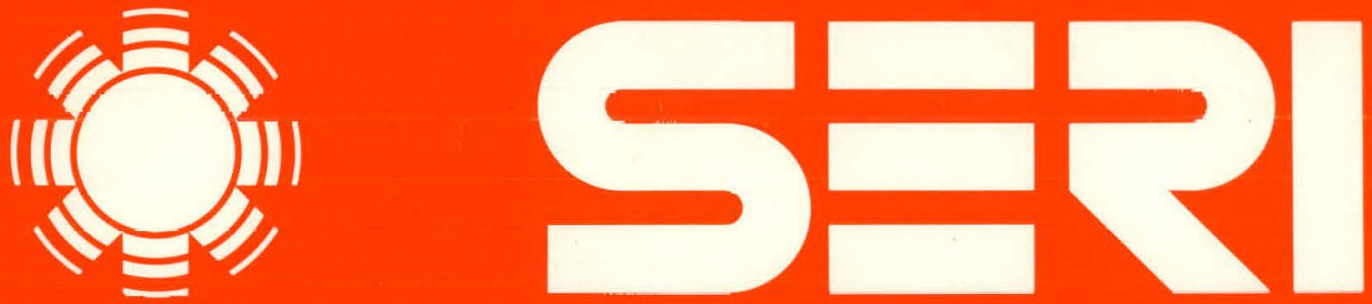

Solar Energy Research Institute A Division of Midwest Research Institute

1617 Cole Boulevard

Golden, Colorado 80401

Operated for the

U.S. Department of Energy under Contract No. EG-77-C-01-4042 


\section{DISCLAIMER}

This report was prepared as an account of work sponsored by an agency of the United States Government. Neither the United States Government nor any agency Thereof, nor any of their employees, makes any warranty, express or implied, or assumes any legal liability or responsibility for the accuracy, completeness, or usefulness of any information, apparatus, product, or process disclosed, or represents that its use would not infringe privately owned rights. Reference herein to any specific commercial product, process, or service by trade name, trademark, manufacturer, or otherwise does not necessarily constitute or imply its endorsement, recommendation, or favoring by the United States Government or any agency thereof. The views and opinions of authors expressed herein do not necessarily state or reflect those of the United States Government or any agency thereof. 


\section{DISCLAIMER}

Portions of this document may be illegible in electronic image products. Images are produced from the best available original document. 
Printed in the United States of America Available from:

National Technical Information Service

U.S. Department of Commerce

5285 Port Royal Road

Springfield, VA 22161

Price:

Microfiche $\$ 3.00$

Printed Copy $\$ 5.25$

\section{NOTICE}

This report was prepared as an account of work sponsored by the United Staies Government. Neither the United States nor the United States Department of Energy, nor any of their employees, nor any of their contractors, subcontractors, or their employees, makes any warranty, express or implied, or assumes any legal liability or responsibility for the accuracy, completeness or usefulness of any information, apparatus, product or process disclosed, or represents that its use would not infringe privately owned rights. 


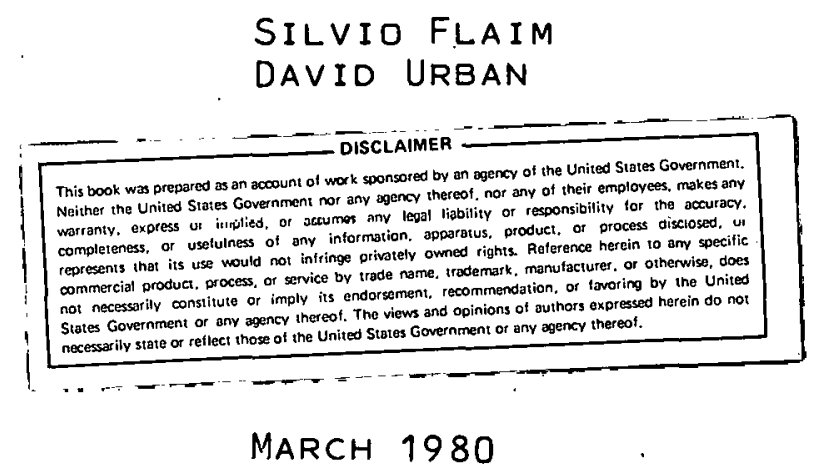

PREFARED UNDER TASK NO. 3346.6

\section{Solar Energy Research Institute}

\section{Cole Boulevard}

Golden, Colorado 80401

A Division of Midwest Research Institute

Prepared for the

U.S. Department of Energy

Contract No. EG.77. C.01.4042 


\section{THIS PAGE \\ WAS INTENTIONALLY \\ LEFT BLANK}




\section{FOREWORD}

This report is the third in a series about agricultural production of biomass feedstocks for energy conversion. The work was completed under Task No. 3346, Subtask 6, "An Evaluation of Crop Residues Used in Direct Combustion Applications." The Analysis Division of the Solar Energy Research Institute is examining two agriculture-for-energy strategies: direct combustion of crop residues and conversion of corn to alcohol. This report examines three direct combustion alternatives for crop residues: on-farm grain drying, grain-elevator grain drying, and electricity generation in utility applications. The systems reviewed for grain drying are commercial prototypes being manufactured for sale in 1980. The cost of these systems are estimates of anticipated sale prices in 1980. These cost estimates will be employed in a macroeconomic analysis to determine the agricultural-sector impacts of large-scale use of agricultural products for energy supply. The authors acknowledge the helpful comments of Bert Mason, Bernard Neenan, and Robert Inman.

Approved for:

SOLAR ENERGY RESEARCH INSTITUTE

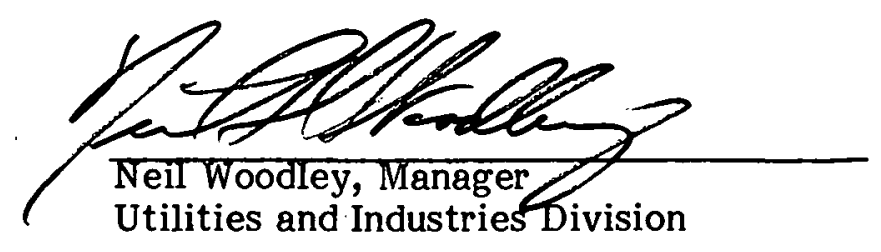




\section{SEㅋ*}




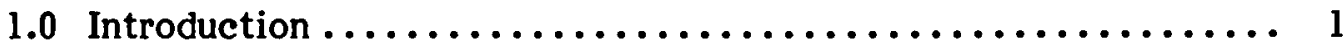

2.0 Residue-Fired Grain Drying Systems ................ 3

2.1 Introduction $\ldots \ldots \ldots \ldots \ldots \ldots \ldots \ldots \ldots \ldots \ldots \ldots \ldots$

2.2 Costs of Crop Residue Harvesting $\ldots \ldots \ldots \ldots \ldots \ldots \ldots \ldots$

2.3 The Value of Crop Residues................... 7

2.4 Transportation Costs $\ldots \ldots \ldots \ldots \ldots \ldots \ldots \ldots \ldots \ldots \ldots$

2.5 Grain Drying $\ldots \ldots \ldots \ldots \ldots \ldots \ldots \ldots \ldots \ldots \ldots \ldots \ldots \ldots$

3.0 Utility Applications $\ldots \ldots \ldots \ldots \ldots \ldots \ldots \ldots \ldots \ldots \ldots \ldots \ldots \ldots$

3.1 Introduction $\ldots \ldots \ldots \ldots \ldots \ldots \ldots \ldots \ldots \ldots \ldots \ldots \ldots \ldots$

3.2 Utility Modifications Costs ................. 17

4.0 Summary and Conclusions $\ldots \ldots \ldots \ldots \ldots \ldots \ldots \ldots \ldots \ldots$

5.0 References and Bibliography $\ldots \ldots \ldots \ldots \ldots \ldots \ldots \ldots \ldots \ldots \ldots$

Appendix A. Principles of Combustion $\ldots \ldots \ldots \ldots \ldots \ldots \ldots \ldots \ldots$

Appendix B. Pollution Control Regulations and Devices .......... 33

Appendix C. Data Tables for Selected Crop-Residue Fuels and

Processing Equipment ................. 37 
SझPl 


\section{LIST OF TABLES}

Page

2-1 Cost Estimates for Corn Stover Harvesting $\ldots \ldots \ldots \ldots \ldots \ldots \ldots \ldots \ldots \ldots \ldots$

2-2 Cost Estimates for Wheat Straw Harvesting.................... 6

2-3 Amount of Nutrients Per Ton of Crop Residues Removed by Type of Crop and the Potential Savings from the Use of Residue Ash (lb/dry ton of residue..$\ldots \ldots \ldots \ldots \ldots \ldots \ldots \ldots \ldots \ldots \ldots \ldots \ldots \ldots \ldots \ldots \ldots$

2-4 Crop Residue Transportation Costs $\ldots \ldots \ldots \ldots \ldots \ldots \ldots \ldots \ldots \ldots \ldots \ldots \ldots \ldots 9$

2-5 1979 Cost Estimates of Propane and Stover-Fired On-Farm Grain

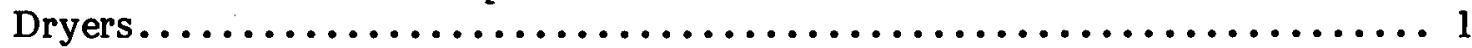

2-6 1979 Cost Estimates of Propane and Stover-Fired Grain Elevator Grain

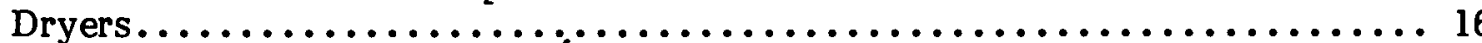

3-1 Capital Costs for Processing and Handling Crop Residues in Stoker Boiler Utility Applications

3-2 Capital, Operations and Maintenance, and Labor Costs in Stoker Boiler Utility Applications ................................. 20

4-1 Cost Summaries for Crop Residue Direct Combustion Applications .......... 23

B-1 Summary of Pollution Control Implementation Plans for States and

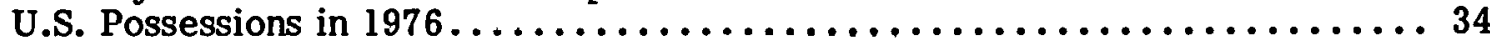

C-1 Energy Values for Selected Solid and Liquid Fuels................. 39

C-2 Properties of Selected Waste Fuels $\ldots \ldots \ldots \ldots \ldots \ldots \ldots \ldots \ldots \ldots \ldots \ldots$

C-3 Processing, Storage, and Conveying Cost Estimates for Utility Boilers in Minnesciq ...................................... 41

C-4 Characteristics of the Ames, Iowa, Generating Station $\ldots \ldots \ldots \ldots \ldots \ldots \ldots$

C-5 Modifications Required to Burn .Crop Residues in the Ames, Iowa, Generating Station 


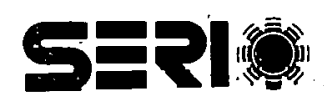




\section{SECTION 1.0}

\section{INTRODUCTION}

Agricultural residues are a potentially large source of renewable biomass energy.* However, transportation and collection costs are high and most existing conversion equipment is not suited for these feedstocks without extensive plant modifications. Wood waste fuels generated in central locations are of ten a disposal problem and merit complete conversion plant replacement or duplication to serve the double purpose of waste disposal and energy self-sufficiency. Except for residues generated at processing plants (i.e., cotton gin millings, rice hulls, peach pits, etc.) most agricultural residues are incorporated in the soil for soil-loss control and soil-fertility maintenance. Crop residues left in the field must be sufficiently valuable as a fuel to justify their collection, transportation, and conversion. One of the most available conversion alternatives in terms of economic and technical feasibility is direct combustion. Literally dozens of furnace and boiler manufacturers sell equipment suitable for burning crop residues.

Despite many successful direct combustion applications in the forest products industry, agricultural crop residues remain largely unused for energy purposes.** Although a structured delivery system for agricultural crop residues does not exist at present, transportation systems and futures markets are well established for food commodities and could easily be extended to incorporate biomass energy feedstocks. Because crop residues are generated in exactly the same places as food crops, transportation systems could be modified easily to handle residues if they were sufficiently valuable. Pollution control regulations appear to have an overriding impact on all types of waste fuel applications. This is particularly true for all direct-combustion systems. Although most biomass has low sulfur content, particulate emissions can be difficult to control when moisture content and particle size of the fuel vary widely. Most equipment designs have been unable to meet emissions standards.

This report examines three direct combustion applications: on-farm grain drying, grain drying at a grain elevator, and using crop residues to fire utility boilers. The examination of grain drying is limited to systems descriptions, considerations for drying equipment selection, and costs of three residue-fired systems currently available. The examinution of utility applications is limited to existing spreader stoker boilers. A few principles of combustion are presented in Appendix $\mathbf{A}$ as a background for pollutioncontrol regulations and how they pertain to equipment design and modifications required to burn crop residues. Because the combustion characteristics and emissions from crop residues have not been thoroughly studied, many parallels are drawn between wood-waste systems and practices currently in use. Appendix B outlines some pollution-control regulations that pertain to solid fuel boilers and devices commonly used to control emissions.

Sectlon 2.0 detuils the cost3 of rccidue-fired grain drying systems, including the costs of residue harvesting alternative uses for residues, transportation costs, and equipment capital and fuel costs. Section 3.0 reviews several cost studies of crop residues used in utility applications.

* Agricultural crop residues are defined here as that part of any crop that would not be harvested given the normal operations of an operating farm.

**Crnp residues have been put to few alternative uses because their value in these uses has not been greater than their nutritive value when put back lnlo llie suil. 
SEP畨 


\section{SECTION 2.0}

\section{RESIDUE-FIRED GRAIN DRYING SYSTEMS}

\subsection{INTRODUCTION}

In the past three decades, corn harvesting techniques have changed from harvesting and drying the corn on the cob to infield shelling of the corn. This change occurred because grain flows easily and shelled corn is less dense, therefore requiring smaller storage and transportation equipment than ear corn. However, loose grain has lower porosity than ear corn. This lower porosity made natural ventilation drying impractical and has led to the use of large quantities of fuel, usually propane or natural gas, to dry the corn.

Low operating temperatures and the relative proximity of drying operations to sources of crop residues make grain drying naturally suited to residue-fired heating systems. However, the low density and high flammability of harvested crop residues make storage a difficult and potentially costly problem. These problems would be relatively small in cases where storage area is available, such as on-farm grain drying. Grain elevators, however, are of ten located near urban areas for transportation reasons. In such cases the fire insurance costs for crop residue storage are believed to be prohibitive (Miles 1979). Another option, though, would be to store the residues on the farm and deliver them only as needed.

Because corn harvest in a state such as Iowa is usually completed in late October or early November, the corn farmer has a very limited time to harvest residues and complete his fall plowing before winter. With additional manpower and equipment, the farmer could harvest the grain and residue simultaneously. Unless systems were designed to facilitate this practice, the additional manpower required could be another limiting factor in residue harvesting and use as a fuel in grain dryers.

This section examines the profitability of grain drying with crop residues both on-farm and at grain elevators. The first part presents the costs of harvesting crop residues, their value in fertility maintenance, and the various types of grain drying systems currently available. The second part examines the cost effectiveness of residue-fired drying systems currently available for farms and grain elevators.

The data presented in this section are exemplary and do not reflect how costs vary by farm size, machine usage, and labor requirements. The residue burners described herein have not been tested fully and equipment lifetimes are uncertain. In addition, the labor required to operate this equipment varies with each farming situation. Research is under way to determine how costs are affected by residue management practices, yields, diversified crop production, and labor availability during harvest. These analyses are presented in forthcoming SERI reports and will be based on data presented here.

\subsection{COSTS OF CROP RESIDUE HARVESTING}

The costs presented here are expressed on a per-ton basis except where specified. It is assumed that collection equipment (excluding tractors) are used only to harvest crop residues. Lower per-ton costs could arise if the harvesting equipment is also used for haying. Varying yields and farm sizes affect these calculations very little if the relationship between the harvesting system and average annual production is known. The farm sizes assumed for these calculations are 400 acres of corn and 750 acres of wheat. The 
differences in farm sizes make the cost estimates for wheat straw somewhat cheaper than corn stover, because total hours of usage will be greater over the 10-year life of the equipment. This effect is ignored for our calculations because farmers seldom keep equipment for a preplanned length of time. These acreage assumptions provide a reference point rather than a generalization about costs, average farm sizes, or average crop plantings.

To estimate costs, each harvesting operation was divided into four factors of production: land, labor, capital, and management. No cost is assessed to land because it is an input into production of the primary grain, oilseeds, etc., and residues are not charged for land to avoid double counting. A $\$ 4.00 / \mathrm{hr}$ return to labor is assumed throughout. This is \$.25 higher than the estimate presented by Edwards and Stonebeiry (1979). Operating and fixed costs for machinery were estimated using worksheets from the Cooperative Extension Services of Iowa, Missnuri, and Oklahoma (Edwards und Stoneberg 1979; Workman 1975; Nelson and Klctlcc 1970). A ielur'll to management of approximately $8 \%$ is also built into the estimates. The costs presented in Tables 2-1 and 2-2 are based on current 1979 prices for new machinery only. These estinules do not represent average charges for the existing stock of harvesting equipment and do not reflect opportunity costs for other farm activities.

Yields of harvestable corn stover, meaning that amount which can be "safely" removed and still be within the soil loss tolerance limits set by the Soil Conservation Service, are assumed to be 1.5 tons per acre. This is a conservative estimate based upon figures of 1.45 tons per acre for conventional tillage and 1.91 tons per acre with conservation tillage reported by Flaim (1979). Since almost all corn is grown by conventional practices (90\% conventional; $10 \%$ reduced tillage) we assumed a value near the lower limit. Wheat straw yields are assumed to be one ton per acre. This is an avcragc eatimate based on .81 tons per acre with conventional tillage and 1.30 tons per acre when conservation tillage practices are followed. This estimate was chosen to reflect the fact that about $60 \%$ of the wheat in the study area was grown with conventional tillage and $40 \%$ with reduced tillage practices. Therefore, one may expect potential yields for residues harvested following conventional tillage practices to be slightly lower and the cost per ton to be slightly higher than those estimated here. For conservation tillage one would expect that the estimated yields are understated and consequently the costs per ton are overstated for the farm sizes under consideration.

Table 2-1 summarizes the cost estimates for harvesting corn stover. Table 2-2 summarizes the cost estimates for wheat straw harvesting. Both tahles include the five most conmon harvesting systems and costs are presented as an average cost per ton for each system. Also included are the custom harvest costs of conventional baling, hig round baling, and stackiniy. No custom charges were available for on-farm hauling in Iowa or for stack hauling in Oklnhoma. Costs for harvesting corn stover ranged from $\$ 12.63$ per ton to $\$ 25.85$ per ton on an engineering basis and from nearly $\$ 17.00$ per ton to $\$ 22.00$ per ton for custom harvesting. Costs for harvesting wheat straw ranged from $\$ 14.11$ per ton to $\$ 21.49$ per ton on an engineering basis and from $\$ 16.24$ per ton to $\$ 23.29$ per ton for custom harvesting. Engineering cost estimates are lower than custom charges, except for conventional bales of corn stover. This exception results from labor cost assumptions rather than any real differences in harvesting practices. For calculations to follow, harvesting costs for big round bales were employed because of their storage characteristics and compatability with residue fired equipment. The development of other types of equipment may employ different types of harvesting equipment. 
Table 2-1. COST ESTIMATES FOR CORN STOVER HARVESTING ${ }^{\mathrm{a}, \mathrm{b}}$

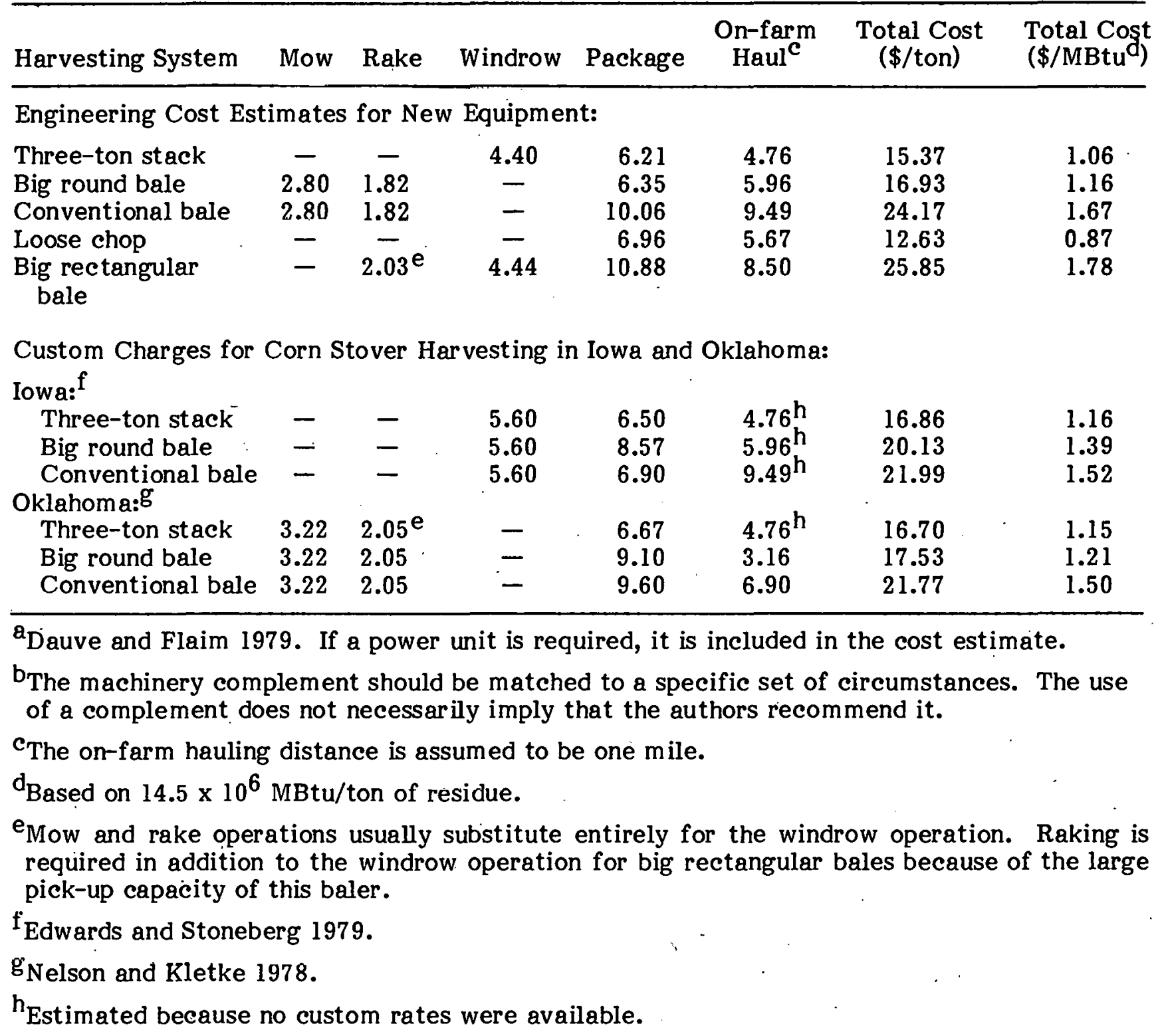


Table 2-2. COST ESTIMATES FOR WHEAT STRAW HARVESTING ${ }^{\mathrm{a}, \mathrm{b}}$

\begin{tabular}{|c|c|c|c|c|c|c|c|}
\hline Harvesting System & Mow ${ }^{c}$ & Rake ${ }^{c}$ & $\begin{array}{l}\text { Swath } \\
\text { (\$/ton) }\end{array}$ & $\begin{array}{l}\text { Package } \\
(\$ / \text { ton })\end{array}$ & $\begin{array}{c}\text { On-farm } \\
\text { Haul }^{\text {(\$) }} \text { (ton) }\end{array}$ & $\begin{array}{c}\text { Total Cost } \\
(\$ / \text { ton })\end{array}$ & $\begin{array}{c}\text { Total Cost } \\
\text { (\$/MBtu) }\end{array}$ \\
\hline \multicolumn{8}{|c|}{ Engineering Cost Estimates for New Equipment: } \\
\hline $\begin{array}{l}\text { Three-ton stacks } \\
\text { Big round bales } \\
\text { Conventional bale } \\
\text { Loose chop } \\
\text { Big rect.angular bale }\end{array}$ & . & & $\begin{array}{c}4.89 \\
3.18 \\
3.18 \\
- \\
4.89\end{array}$ & $\begin{array}{l}6.48 \\
6.03 \\
9.28 \\
9.25 \\
9.14\end{array}$ & $\begin{array}{l}4.62 \\
7.31 \\
9.03 \\
4.86 \\
6.40\end{array}$ & $\begin{array}{l}15.99 \\
16.52 \\
21.49 \\
14.11 \\
20.43\end{array}$ & $\begin{array}{r}1.10 \\
1.14 \\
1.48 \\
.97 \\
1.41\end{array}$ \\
\hline \multicolumn{8}{|c|}{ Custom Charges for Wheat Straw Harvesting In Iowa and Oklahoma: } \\
\hline $\begin{array}{l}\text { Three-ton stack } \\
\text { Big round bale } \\
\text { Conventional bale }\end{array}$ & $\begin{array}{l}3.10 \\
3.10 \\
3.10\end{array}$ & $\begin{array}{l}2.50 \\
2.50 \\
2.50\end{array}$ & $\begin{array}{l}- \\
-\end{array}$ & $\begin{array}{r}6.50 \\
10.14 \\
7.67\end{array}$ & $\begin{array}{l}1.63^{h} \\
7.31^{h} \\
9.03^{h}\end{array}$ & $\begin{array}{l}10.72 \\
23.05 \\
22.30\end{array}$ & $\begin{array}{l}1.29 \\
1.77 \\
1.72\end{array}$ \\
\hline $\begin{array}{l}\text { Oklahoma:g } \\
\text { Three-ton stack } \\
\text { Big round bale } \\
\text { Conventional bale }\end{array}$ & $\frac{-}{-}$ & - & $\begin{array}{l}4.95^{\mathrm{e}} \\
4.95 \\
4.95\end{array}$ & $\begin{array}{r}6.67 \\
10.70 \\
10.67\end{array}$ & $\begin{array}{l}4.62^{h} \\
3.71 \\
7.67\end{array}$ & $\begin{array}{l}16.24 \\
19.36 \\
23.29\end{array}$ & $\begin{array}{l}1.25 \\
1.49 \\
1.79\end{array}$ \\
\hline
\end{tabular}

${ }^{a}$ Dauve and Flaim 1979. If a power unit is required, it is included in the cost estimate.

$\mathrm{b}_{\text {The }}$ machinery complement should be matched to a specific set of circumstances. The complement used is not meant to imply that the authors recommend it.

'Swath operations substitute for mowing and raking.

The on-farm hauling distance is assumed to be one mile.

$\mathrm{e}_{\text {Based on } 14.5 \mathrm{MBtu} / \text { ton or residue. }}$

$\mathrm{f}_{\text {Edwards and Stoneberg } 1979 .}$

$\mathrm{g}_{\mathrm{Nelson}}$ and Kletke 1978.

$\mathrm{h}_{\text {Estimated because no custom rates were available. }}$ 
Custom operators allow farmers more flexibility in timing residue collection. Custom operators could begin collection of residues shortly after the grain harvest begins. Alternatively, if the grain is custom-harvested the farmer who owns haying equipment could follow the custom operator. Either alternative allows the landowner maximum utilization of this land and equipment and a chance to avoid a shortage of labor on the farm. Custom rate charges (which do not reflect these considerations) are presented for comparisons with our cost estimates.

\subsection{THE VALUE OF CROP RESIDUES}

The value of crop residues has been interpreted in many different ways. Corn stover is jointly produced with corn grain. However, few analysts have tried to separate the cost of production into its appropriate components because such distinctions are usually arbitrary. Typically, the amount of residues available for any other purpose besides incorporation in the soil is determined from estimates of "acceptable soil loss limits" determined by the Soil Conservation Service for a particular soil type. "Excess" residues are defined as that amount produced over the minimum required to maintain soil fertility and control erosion. A cost may be assessed for replacing nutrients removed when residues are collected, but this will vary with crops, soil types, residue removal rates, weather, and tillage practices. Average amounts of nutrients per ton of crop residue removed by type of crop and potential savings from the use of residue ash are presented in Table 2-3. No dollar values are assigned to these estimates because nutrients become available as the material decomposes, which requires discounting the nutrients and their respective prices as they become available. The estimates in Table 2-3 ignore the impact on biological activity in the soil, but these impacts are not well understood and cannot be quantified.

Harvesting crop residues eliminates two machine operations in the fall: chopping and discing. The cost of these operations is not addressed here, but would increase the value of the residue by a small, unknown amount. It is assumed further that the quantity of residues left after harvesting is sufficient to control erosion and to sustain crop production economically and indefinitely.*

Table 2-3 illustrates the most notable aspect of burning crop residues, the destruction of available nitrogen which requires high levels of solar energy to "fix" in plunts. Other conversion equipment, including anaerobic digestors, animals, and humans, destroy very little of the nitrogen component and if residues from methane generation, manure, and sewage sludge are reapplied to the soil, significant conservation of available nitrogen can be achieved (Stanford 1980). Redistribution of ash would incur other costs, but this cost could be minimized by incorporating this activity in other field operations.

*The value of crop residues in controlling erosion has been estimated from a regional linear programming model of the agricultural sector in Iowa. Using different crop production practices and crop rotations, alternative solutions to the model were obtained with soil-loss unconstrained and constrained to levels that occur without residue removal. Different production practices and rotations were forced into solution to satisfy the soil loss constraint. The value of crop residues in erosion control were calculated based upon the differences in the objective function with the unconstrained and constrained uses. The calculated values were very low, ranging from $\$ 0.015$ to $\$ 0.11$ per ton for the level of removal evaluated (Short et al. 1978). 
Table 2-3. AMOUNT OF NUTRIENTS PER TON OF CROP RESIDUE REMOVED BY TYPE OF CROP AND POTENTIAL SAVINGS FROM THE USE OF RESIDUE ASH FROM DIRECT COMBUSTION (lb/dry ton of residue)

\begin{tabular}{|c|c|c|c|c|c|c|}
\hline \multirow[b]{3}{*}{ Crop } & \multicolumn{6}{|c|}{ Nutrient } \\
\hline & \multicolumn{2}{|c|}{ Nitrogen } & \multicolumn{2}{|c|}{ Phosphorus } & \multicolumn{2}{|c|}{ Potássium } \\
\hline & $\begin{array}{l}\text { Lost in } \\
\text { Removal }^{\mathrm{a}}\end{array}$ & $\begin{array}{l}\text { Returned } \\
\text { with Ash }\end{array}$ & $\begin{array}{l}\text { Lost in } \\
\text { Removal }^{a}\end{array}$ & $\begin{array}{l}\text { Returned } \\
\text { with Ash }\end{array}$ & $\begin{array}{l}\text { Lost in } \\
\text { Removal }^{\mathrm{a}}\end{array}$ & $\begin{array}{l}\text { Returned } \\
\text { with Ash }\end{array}$ \\
\hline Corn & 22.22 & 0.00 & 3.59 & $\cdot 1.85$ & 26.75 & 5.38 \\
\hline Soybeans & 45.00 & 0.00 & 1.38 & 3.33 & 20.75 & 6.25 \\
\hline Wheat & 13.33 & 0.00 & 1.45 & .90 & 19.37 & 6.25 \\
\hline
\end{tabular}

${ }^{a_{W}}$ White and Collins 1976.

b Bhagat, Davitian, and Pouder 1979.

\subsection{TRANSPORTATION COSTS}

Transportation of crop residues to an on-farm residue-fired grain dryer can be accomplished in several ways. Stackwagons or loose chop harvest systems are feasible for hauling crop residues over short distances. Large round bales or big square bales are moved with specially designed (and currently available) bale movers. The costs of corn stover and wheat straw harvesting presented in Tables 2-1 and 2-2 include charges for hauling residues one mile.

Costs for transporting residues to a powèr plant can be determined by an engineering cost estimate or the use of current charges per ton/mile for hay and straw. Since the volume constraint on trucks is usually exceeded before weight becomes a consideration, light-duty trucks with trailers might be an economical alternative for some farmers.

Table 2-4 presents a summary of crop residue transportation costs in the studies we examined. A detailed engineering cost estimate is adapted from Short et al. All other estimates are expressed in ton-mile charges, for comparison. Differences in cost assumptions among studies could not be ascertained. We have updated fuel, oil, and labor costs from their 1978 estimates. Table 2-4 shows that even with more recent costs of fuel, costs per ton mile acconring to Short et al, are about hnif thnge used by Koelsoli $u t$ al. and if the lower estimate is used, half that by Abdallah. The costs of moving stacks are very similar for all studies. Charges per ton mile range. from $\$ 0.32$ to $\$ 0.343$.

The largest costs of transporting residues are fixed costs (interest and depreciation), overhead, fuel, and wages. Fuel costs can be expected to become more important as the prices of gasoline and diesel fuel increase.

Transfer costs are those costs incurred in loading and unloading crop residues. Transfer costs are included in the ton-mile charges of Table 2-4. Short et al. estimate that transfer costs amount to about $3 / 4$ of an hour of effort per truckload. Most of the transfer costs are labor charges for the truck driver who must wait while residues are loaded and unloaded. Big round bales are less expensive to transport than stacks because 
Table 2-4. CROP RESIDUE TRANSPORTATION COSTS ${ }^{\mathfrak{a}}$

\begin{tabular}{|c|c|c|c|c|}
\hline \multirow[b]{2}{*}{ Item } & \multicolumn{4}{|c|}{ Unit Cost } \\
\hline & \$/year & & $\$ /$ ton & \\
\hline $\begin{array}{l}\text { Fixed Costs } \\
\text { Interest and Depreciation } \\
\quad \text { (initial cost of } \$ 23,808 \text { ) } \\
\text { License fees and highway expenses } \\
\text { Insurance } \\
\text { Maintenance and repairs } \\
\text { Overhead and management }\end{array}$ & $\begin{array}{r}3,757.93 \\
440.00 \\
624.56 \\
1.521 .17 \\
3,189.47\end{array}$ & & $\begin{array}{l}0.1578 \\
0.0185 \\
0.0262 \\
0.0639 \\
0.1340\end{array}$ & \\
\hline Subtotal & & & & 0.4004 \\
\hline & $\$ / \mathrm{mile}^{\mathrm{d}}$ & & $\$ /$ ton & \\
\hline 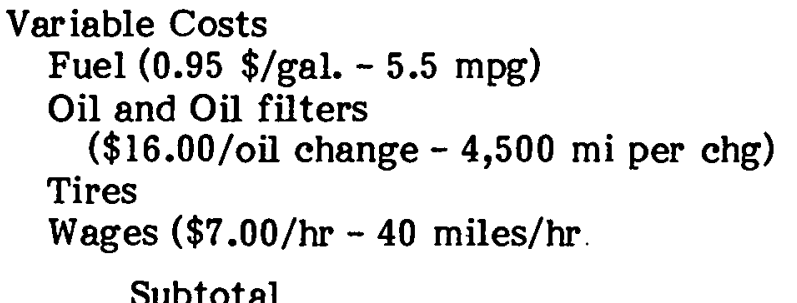 & $\begin{array}{c}0.1727 \\
0.0035 \\
0.0245 \\
0.1750 \\
.\end{array}$ & 3757 & $\begin{array}{l}0.1495 \\
0.0032 \\
0.0019 \\
0.1557\end{array}$ & 3103 \\
\hline & \$/year & & $\$ /$ ton & \\
\hline $\begin{array}{l}\text { Transfer Costs } \\
\text { Wages }(7.00 / \mathrm{hr} \times .75 \mathrm{hr} / \text { load })\end{array}$ & 5.25 & & 0.4375 & \\
\hline $\begin{array}{l}\text { Total costs per ton for } 10 \mathrm{mi} \text { round trip } \\
\text { (including transfer costs) } \\
\text { Cost per ton mile } \\
\text { Short et al. (1978) } \\
\text { Koelsch, Clark, and Larson (1977) } \\
\text { (based on } 20 \text { mi round trip) } \\
\text { Blg rourid bules } \\
\text { Stacks } \\
\text { Miles (1978) stacks } \\
\text { Abdallah (1978) } \\
\text { Big round bales } \\
\text { Stacks } \\
\text { Loose chop }\end{array}$ & , & & $\begin{array}{l}0.235 \\
0.32 \\
0.32 \\
0.17 \\
0.343 \\
0.393\end{array}$ &. \\
\hline
\end{tabular}

${ }^{\mathbf{a}_{\text {Short }} \text { et al. } 1978 .}$

$\mathrm{b}_{\text {Annual interest and depreciation charges are calculated using a capital recovery factor }}$ assuming a salvage value after 8 years of $\$ 5,692$ and a discount rate of $10 \%$ (double declining balance depreciation schedule).

${ }^{c}$ Assumed to equal $65 \%$ of initial purchase price.

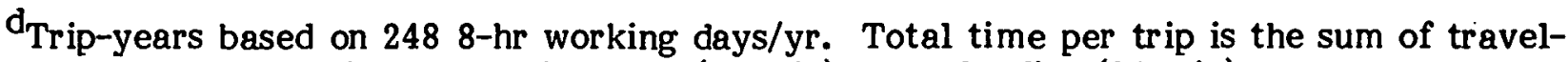
ing time, at $40 \mathrm{mph}$, plus loading time $(30 \mathrm{~min})$ and unloading $(15 \mathrm{~min})$.

e Stacks are transported by a stack mover, large round bales by goose-neck trailer, and loose-chnp hy tractor trailer truck. 
their density is higher, and transporting big round bales is easier and losses are smaller than transporting stacks.

\subsection{GRAIN DRYING}

Typically, corn is harvested with 23\% MCWB (moisture content wet basis) and must be dried to about 15\% MCWB to avoid spoilage in storage. Grain drying can be accomplished in a number of different ways, depending upon the amount of grain to be dried and local weather conditions. The differences between on-farm and grain elevator drying systems are primarily differences in scale. Grain elevators characteristically handle larger quantities of grain and generally select continuous-flow systems to avoid the delays that occur while the grain is being transferred in and out of a batch dryer. Small farms, on the other hand, of ten find batch systems to be economical. Scale differences aside, lliel'e ure three baslc methods of drying grain: (1) high-temperature drying with a separate cooling stage, (2) dryeration, and (3) low-temperature drying.

High-temperature systems expose the grain to temperatures ranging from $160^{\circ} \mathrm{F}$ to $250^{\circ} \mathrm{F}$. The temperature extremes that corn can withstand without damage vary with its moisture content. The systems that utilize temperatures as high as $250^{8} \mathrm{~F}$ do so at the beginning of the cycle when the grain has a relatively high moisture content. The final temperatures as the grain approaches $15 \%$ MCWB are usually around $160^{\circ} \mathrm{F}$. Once the grain has reached the desired moisture content, it is cooled either in the dryer or in a separate system. The efficiency of the system is indicated by the temperature and humidity of the exhaust air. If there is excess drying capacity in the exhaust air, efficiencies are lower.

Dryeration refers to a system in which the grain is dried in a high-temperature dryer to about three percentage points above the desired moisture content. The grain is then transferred while hot to another bin and allowed to steep for 8-10 hours. The steeping allows the moisture in the middle of the kernel to distribute itself morc cvenly throughout the kernel, increasing the moisture content of the outer areas of the kernel. The grain is then cooled, by means of the bin's aeration system. After cooling, the grain's moisture content is usually about three points lower than it was when it left the dryer. This type of system is more efficient than others identified because it extracts the last remaining moisture without heating. The disadvantage of the system is that it is difficult to manage and is not easily adapted to continuous-flow systems.

Low-temperature drying uses large volumes of ambient or slightly warmer air to dry the grain. This requires long drying periods-as much as fifty-five days for corn that started at $24 \%$ MCWB with $40^{\circ} \mathrm{F}$ air (Doane's Agricultural Report 1979, p. 354.3). Low-temperature drying is very efficient hut requires more mnnngement than high-temperulurc drying. Its low operating temperature makes it suitable for other types of solar equipment. However, its long drying time and high labor requirements make it less suitable for large enterprises.

Hybrid systems have tremendous potential for energy conservation. For farms where low-temperature drying is too slow, a high-temperature system could be used to bring the grain down to around $20 \% \mathrm{MCWB}$. The remaining moisture could be removed with a lowtemperature system. High-temperature systems are most efficient at high moisture levels while low-temperature drying is best managed at low moisture levels where spoilage is less of a problem. Such a hybrid system can reduce energy consumption by $44 \%$ while increasing the capacity of a high-temperature dryer by a factor of two (Doane's 1979, p. 358.4). 
The several types of high-temperature drying systems can be classified into three general ones: (1) batch systems, (2) in-storage drying, and (3) continuous-flow systems. A batch system is one in which a quantity of grain is transferred into a dryer, either a special bin or a separate unit, and the entire batch is dried and then cooled, either in the same system or separately. Batch systems tend to be inexpensive and have high drying speeds. Their major disadvantage is that they require more labor to operate.

In-storage drying systems use the final storage container as the dryer. Grain is added daily in layers while hot air is forced up from the bottom. The technique is to apply wet grain at roughly the same rate that the drying zone is moving up the grain pile. This type of system is difficult to manage and its slow drying rate and inflexibility make it unsuitable for many applications.

Continuous-flow systems are particularly popular for large operations. The wet grain can be placed in a holding tank and the system automatically transfers the wet grain to the dryer and the dry grain to storage. The most common configuration is one in which wet grain is placed at the top of a $1-\mathrm{ft}$-diameter column through which hot air is forced, perpendicular to the flow of the grain. The grain descends the column and is metered out the bottom. Some larger systems supply progressively cooler air as the grain descends the column, taking advantage of the grain's ability to withstand higher temperatures at higher moisture contents. Many systems cool the grain at the bottom of the column and use the extracted heat to preheat some of the drying air. While efficiency is gained by extracting the heat from the dried grain, heat is often lost because the exhaust air from the drying section is not saturated (Middle State Manufacturing 1979).

Continuous in-bin drying systems can avoid exhaust air heat losses by having the grain flow opposite the direction of air flow. This counterflow situation utilizes almost all the available heat in the air stream. One such system, marketed by Middle State Manufacturing of Columbus, Nebraska, uses a horizontal sweep auger to unload dry grain from the bottom of a pile that can range from 5-19 ft thick. The hot air is blown in from the bottom and passes up through the pile. Wet grain is applied to the top of the pile. The manufacturers recommend operating the system when the grain depth is $5 \mathrm{ft}$ or greater, with an upper limit of about $19 \mathrm{ft}$ (Joseph 1979). Exhaust air losses are very small due to the counterflow operation. Mathews Company of Crystal Lake, Illinois, manufacturers a system of this type that also uses the heat from the dry grain as it is cooled (Mathews Company 1979).

When selecting a drying system, the farmer makes his decision based on the suitability of the system for the climatic conditions and harvest practices of his farm. The size of the farm greatly determines the necessary capacity and drying rates. The type of enterprises in which the farmer is involved also strongly influences his drying requirements. Grain that is stored only until spring can be stored at 15.5\% MCWB while grain that is expected to be stored through the summer must be dried to $13 \% \mathrm{MCWB}$. Likewise, climate and breed of corn planted affect the drying rate by varying the initial moisture content of the grain. To compare the two on-farm residue-fired systems, the following hypothetical assumptions are made. The farm has 400 acres of corn with an average yield of $130 \mathrm{bu} /$ acre. The moisture content of the harvested corn averages $22 \% \mathrm{MCWB}$, to be dried to $15 \% \mathrm{MCWB}$. The harvest rate runs from $300 \mathrm{bu} / \mathrm{hr}$ to $600 \mathrm{bu} / \mathrm{hr}$. Harvest is assumed to take place primarily in October with an average daytime temperature of $52^{\circ} \mathrm{F}$. These conditions were selected to represent reasonable, if not typical, conditions in Eastern Iowa, a major corn-producing area.

Grain elevator operators must consider many of the same factors that farmers do when selecting grain-drying systems. Local harvest and weather conditions will determine the 
moisture content of the grain that the elevator receives. The necessary drying rate will be controlled by the capacity of the elevator and the number of farms that it serves. For this analysis, a medium-sized grain elevator is hypothesized. The elevator dries about $700,000 \mathrm{bu}$ of corn/yr from $22 \%$ to $15 \% \mathrm{MCWB}$, on the average. The average ambient air temperature assumed is $50^{\circ} \mathrm{F}$ during the hours in which the grain is dried.

\subsubsection{On-Farm Residue-Fired Grain Dryers}

A total of five residue-fired grain dryers were identified. Two are not available commercially. One is located at Pioneer Seed Corn Company, Marengo, Indiana, and the other at Waste Combustion Corp., Richmond, Virginia. Other design work on residue fired grain dryers is being performed in Agricultural Engineering Departments at Iowa State University, Purdue, University of California-Davis, and Kansas State University. Kajewski built a primitive residte-fired grain dryer for a M.S. project at Iowa State University. A cross baffle design was used to reduce emissions of fly ash, but problems were encountered with conveying systerns, fan size, unburned hydrocarbons, und the hydraulic feeding mechanism (Kajewski 1977).

Three residue-fired drying systems currently being developed for sale in 1980 are the basis for the cost comparisons that follow. All utilize in-bin drying systems but differ somewhat in type. The first system being developed for sale is a continuous in-bin system. The residue burner accepts big round bales, approximately $5 \mathrm{ft}$ long by $5-7 \mathrm{ft}$ in diameter. Up to two bales can be loaded by a standard tractor loading device onto a rack. Once the bales are on the rack, the device automatically loads them into the burning chamber. The two-bale rack allows the device to burn without reloading the rack for about four hours. This interval is probably sufficient to not seriously interfere with harvest. However, it is necessary that the controls be operated to load the next bale into the burner about every 1-1/2 hours. This function could be performed by almost anyone and would not necessarily require the attention of workers involved with the harvest.

Assuming the farmer already has a number of storage bins with the necessary equipment to transfer between bins, the cost of changing an existing $30-\mathrm{ft}$ diameter bin into a continuous grain dryer would be approximately $\$ 25,000$ for a residue burner and about $\$ 19,500$ for a propane burner. The bin costs approximately $\$ 6,700$ installed.

A prototype of this first system has successfully dried a 50,000-bu corn harvest during trials in 1979. The system dried 6,000 to 7,000 bu/18-hr day. Moisture content was reduced from $28 \%$ to $14.5 \%$ MCWB. Emissions from the residue and corn burner are virtually eliminated in three ways. The burner is a top-down design which pulls unburned gases and particulates from the top through the firebrick-lined grate. Residence time of gases is increased and most combustion products are pullcd into the fire wliere they are consumed by the $1200^{\circ}-1800^{\circ} \mathrm{F}$ temperature. A fly ash trap is incorporated in the system to keep ashes out of the drying system and grain. After combustion gases pass through the fly ush trap they are mixed approximately 11 to 1 with outside air. This mix is then blown from bottom to top through the grain and vented out the top of the bin. The grain acts as a huge filter to removc all remaining impurities. The grain from the residue burner appears to be of comparable quality and uniform moisture content as grain dried with propane.

The first system may be adapted to burn grain. This burner costs about the same as the residue burner. Estimates of the fuel costs for the three fuels-propane, corn stover, and corn-are presented in Table 2-5. Off-quality grain should be used instead of \# 2 corn if 
Table 2-5. 1979 COST ESTIMATES OF PROPANE AND STOVER-FIRED ON-FARM GRAIN DRYERS

\begin{tabular}{|c|c|c|c|c|c|c|c|}
\hline Grain Dryer/Fuel Type & $\begin{array}{c}\text { Capital } \\
\text { Cost }\end{array}$ & $\begin{array}{l}\text { Energy } \\
\text { Ccntent } \\
\text { Per Unit }\end{array}$ & $\underset{\text { Efficlency }}{\text { Heating }}$ & $\begin{array}{c}\text { Fuel } \\
\text { Cost } \\
\text { Per Unit }\end{array}$ & $\begin{array}{c}\text { Units to Dry } \\
52,000 \mathrm{Bu} \\
\left(348 \times 10^{6} \mathrm{Btu}\right) \\
\text { From } 23 \% \mathrm{MCW} \\
\text { to } 15 \% \mathrm{MCWR}\end{array}$ & $\begin{array}{l}\text { Total } \\
\text { Fuel } \\
\text { Cost }\end{array}$ & $\begin{array}{c}\text { Fuel } \\
\text { Savings } \\
\text { Over Propane }\end{array}$ \\
\hline $\begin{array}{l}\text { 1st Type } \\
\text { Propane } \\
\text { Residue } \\
\text { \#2 Corn }\end{array}$ & $\begin{array}{c}\$ 19,500^{\mathrm{c}} \\
25,000^{\mathrm{c}} \\
25,000^{\mathrm{c}}\end{array}$ & $\begin{array}{c}91,600 \text { Btu/gal. } \\
7,250 \text { Btu/lb } \\
9,000 \text { Btu/lb }\end{array}$ & $\begin{array}{l}.95 \\
.81 \\
.88\end{array}$ & $\begin{array}{c}0.65 / \mathrm{gal} \\
16.93 / \text { ton }^{\mathrm{T}} \\
2.50 / \mathrm{bu}\end{array}$ & $\begin{array}{c}4,000 \mathrm{gal}^{\mathrm{e}} \\
30 \text { tons }^{\mathrm{f}} \\
785 \text { bu }^{\mathrm{g}}\end{array}$ & $\begin{array}{r}\$ 2,600.00 \\
525.20 \mathrm{i} \\
1,980.00^{\mathrm{i}}\end{array}$ & $\begin{array}{r}\$ 2, \overline{080.00} \\
620.00\end{array}$ \\
\hline $\begin{array}{l}\text { 2nd Type } \\
\text { Propane } \\
\text { Residue }\end{array}$ & $\begin{array}{l}20,000 \stackrel{j}{j} \\
27,000^{j}, k\end{array}$ & $\begin{array}{c}91,000 \text { Btw/gal: } \\
7,25 \mathrm{Ctu} / 1 \mathrm{~b}\end{array}$ & $\begin{array}{l}.95 \\
.81\end{array}$ & $\begin{array}{l}0.65 \\
16.93 / \text { ton }^{h}\end{array}$ & $\begin{array}{r}5,200 \\
3.8 \text { tons } 1\end{array}$ & $\begin{array}{r}3,380.00 \\
643.00^{i}\end{array}$ & $2, \overline{740.00}$ \\
\hline
\end{tabular}

'See Appendix, Table A-1.

b Ambient temperatures of $520^{\circ} \mathrm{F}$ assumed (9:00 E.m. - 9:00 p.m. October average temperatures in Dubuque, Iowa).

${ }^{c_{P r i c e}}$ includes burner, perforated floor, floor supports, 7.5 H.P. unloader, 50 H.P. fan, 1 H.P. leveler, propane burner, transition ducts, roof air outlets, and electrical panel. Approximate prices inflated 15\% from 1978 (excludes tax credits). Residue burner cost reported in Nebraske Farmer Magezine, November 18, 1978.

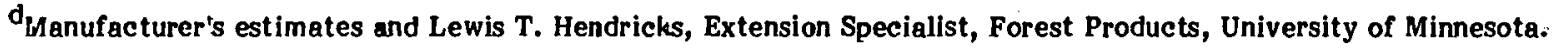

$\mathrm{e}\left(348 \times 10^{6} \mathrm{Btu}\right) /((91,600 \mathrm{Btu} / \mathrm{gal})(.95))=4,000 \mathrm{gal}$.

$\mathrm{f}\left(348 \times 10^{6} \mathrm{Btu}\right) /(7,250 \mathrm{Btu} / \mathrm{Ab})(.81)=(60,000 \mathrm{lb}) \div(2,000 \mathrm{lb} /$ ton $)=30$ tons.

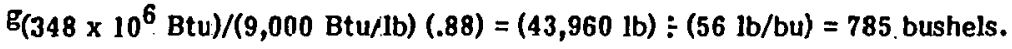

${ }^{\mathrm{h}}$ Dauve and Flaim 19r9.

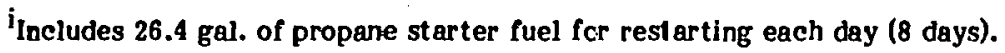

jApproximate installed cost for all equipment.

$k_{\text {Anticipated list sales price. }}$

${ }^{1}$ More fuel is reguired for this system because of its use of an air-to-air heat exchanger. 
it is available because it is considerably cheaper and has few alternative uses (Joseph 1979). Availability of such grain varies considerably, so the cost of \#2 corn was used as the fuel cost. The collection cost for a bale was based on average rates for Iowa (Dauve and Flaim 1979). The heating requirements were based on data provided by the manufacturer for their equipment. With an operating temperature of $160^{\circ} \mathrm{F}$ and an ambient temperature of $60^{\circ} \mathrm{F}$, the dryer averages about $1,350 \mathrm{Btu}$ per pound of water extracted (Joseph 1979). This figure was adjusted to the $52^{\circ} \mathrm{F}$ ambient temperature that can be expected in October (Doane's 1979).

Another manufacturer has a top-loading design for on-farm grain dryers. The capital costs for this system are nearly identical to the side-loading version but the labor costs are much higher. Automatic feeding devices are available but have significantly higher capital costs, which are not reflected in Table 2-5. This system was not reported in detail because of its higher costs and inefficient loading design.

Costs for big round bales of corn stover are selected because the burner can be automatically loaded with these bales and corn stover can usually be found where corn grain is dried. Wheat straw is a suitable substitute, as well. The grain burner can be fed automatically with an auger system. The residue burner is large and costs an additional $\$ 5,500$ more than the propane system. For the hypothetical farming situation described in Table 2-5, the fuel savings are about $\$ 2,000$ for the stover-fired grain dryer and about $\$ 620$ for the corr burner. The fuel savings from burning grain would be smaller than this estimate if off-quality grain were not available. A farmer could use part of the crop to dry the rest. These savings are for eight $16-\mathrm{hr}$ days of operation, one farm's average output. However, the burner is portable. If two farmers with 50,000-bu crops purchased a residue burner, the payback period could be less than one month. Further, the burners could be used for space heating farrowing houses, barns, or equipment sheds when not being used for grain drying.

The second system examined here also uses an in-bin drying system, but one of a different configuration from the first system. The dryer can be operated either in a batch or continuous mode depending upon how it is instrumented and equipped. The system dries a 32-in.-thick layer of grain on a drying floor that is $4 \mathrm{ft}$ below the eaves. Hot air from the burner mixes with warm air from the grain cooling below and passes through the wet grain layer. When the grain is dried, it is dumped on the cooling pile below where its heat is extracted and used to dry more grain.

The residue burner consists of a cubical heat chamber with side dimensions of $10 \mathrm{ft}$. The burner is double-walled with the drying air passing between the walls as it is heated by the wall surrounding the combustion air. By using this heat exohanger system, the quality of the drying air is assured. The heat chamber is loaded through large double doors on the side with a tractor lifting device and can accept either big round bales or small stacks of crop residue. The nature of the loading system requires the use of $a$ tractor each time the system is loaded. Depending on the size of the stack or bale and the drying rate, loading could occur at intervals ranging from two to six hours. Because the tractors are probably in use in the field during harvest, loading could be a problem if the interval was as low as two hours.

While this system does extract the heat from the dry grain, data used in our comparisons show that this system is less efficient than the first system because of the use of heat exchangers. The second system has only been tested with one prototype. The company is in the process of manufacturing 12 for testing on sample farms. The drying system data provided by the company was not sufficiently precise to allow the same detailed analysis 
used for the first system. The company estimates that one gal. of propane will dry five to nine bu of corn from $25 \%$ to $15 \%$ MCWB. A comparison was made based on these assumptions (Table 2-5).

The savings from the second residue grain dryer are comparable to those of the first, about $\$ 2,700$ or half the burner cost for a 52,000-bu crop (Table 2-5). However, this system has not been fully tested. In addition, the burner has substantial labor requirements that occur during harvest that have not been accounted for.

\subsubsection{Residue-Fired Grain Dryers for Grain Elevators}

Table 2-6 presents current costs for a grain elevator residue-fired burner. The system is assumed to be installed in a steel bin $42 \mathrm{ft}$ in diameter and $22 \mathrm{ft}$ high. The installed cost of this bin is about $\$ 14,000$, but is not included in burner costs. Assuming that 700,000 bu of corn are to be dried from an average of 23\% MCWB to 15\% MCWB, about 5,500 MBtu are required for ambient temperatures of $50^{\circ} \mathrm{F}$. After efficiency losses are accounted for, this is equivalent to 468 tons of corn stover or 63,200 gal. of propane. Using $\$ 16.93 /$ ton for on-farm harvest and hauling and adding a $\$ 2.00 /$ ton hauling charge (10 $\mathrm{mi}$ average hauling radius at 0.20 /ton $\mathrm{mi}$ ) and $\$ 10.00 /$ ton profit for the stover, fuel savings amount to about $\$ 27,000$ per harvest year. This savings is about 3 times the cost of the residue burner alone, about the same as the cost for the drying equipment. Even at $\$ 50 /$ ton for corn stover, fuel savings are almost $\$ 18,000$. 
Table 2-6. 1979 COST ESTIMATES OP PROPANE AND STOVER-FIRED GRAII ELEVATOR GRAIN DRYERS

\begin{tabular}{|c|c|c|c|c|c|c|c|}
\hline Fuel Type & $\begin{array}{c}\text { Capital } \\
\text { Cost }\end{array}$ & $\begin{array}{l}\text { Energy } \\
\text { Content } \\
\text { Per Unit }\end{array}$ & $\begin{array}{c}\text { Heating } \\
\text { Efficiency }\end{array}$ & $\begin{array}{l}\text { Fuel } \\
\text { Cost } \\
\text { Per Unit }\end{array}$ & $\begin{array}{l}\text { Units to Dry } \\
700,000 \mathrm{Bu} \\
\left(5500 \times 10^{6} \mathrm{Btu}\right) \\
\text { From } 23 \% \mathrm{MCWB} \\
\text { to } 15 \% \mathrm{MCWB}\end{array}$ & $\begin{array}{l}\text { Total } \\
\text { Fuel } \\
\text { Cost }\end{array}$ & $\begin{array}{c}\text { Fuel } \\
\text { Savings } \\
\text { Over Propane }\end{array}$ \\
\hline Propane & $22,500^{8}$ & $91,600 \mathrm{Btu} / \mathrm{gal}$. & $.95^{b}$ & $\$ 0.65 / \mathrm{gal}$ & $63,200 \mathrm{gal} .^{d}$ & $\$ 41,100$ & - \\
\hline Residue & $23,000^{a}$ & $7,250 \mathrm{Btu} / \mathrm{lb}$ & $.81^{b}$ & $\$ 29.00 / T^{c}$ & 468 Ions $^{\mathrm{e}}$ & $\$ 13,700^{f}$ & $\$ 27,400$ \\
\hline
\end{tabular}

aprice includes residue bumer if applicable, Eerforatec noor, floor supports, 15 H.P. botton urIoader, 100 H.P. fan, 2 H.P. levelers, propane burner, transition ducts, roof air ducts, and electrical panel. Prices inflated $15 \%$ from 1978 (excludes tax credits). Price does not include steel bin. $42^{*}$.jiameter, $22^{\prime}$ high, approximately $\$ 13,900$ installed.

bManufacturers estimate anj Lewis T. Hendrick, Extension Specialist, Forest Products, University of Minnesota.

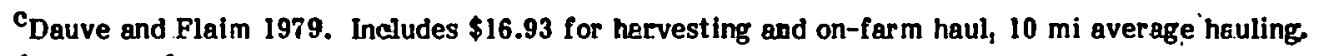

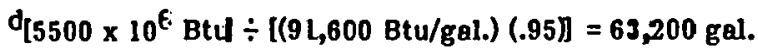

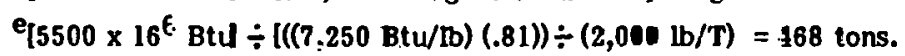

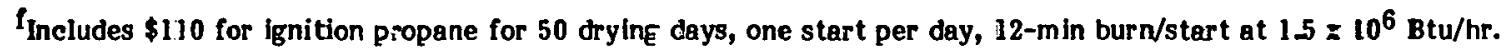




\section{SECTION 3.0}

\section{UTIITYY APPLICATIONS}

\subsection{INTRODUCTION}

The costs of burning crop residues in utility applications depend on the costs of harvesting and transporting residues, and the costs of modifying existing boilers and materials handling systems. Substantial storage costs may be incurred if the utility has to store residues over a crop year from an annual herbacious crop. However, on-farm storage could allow the utility to schedule deliveries according to its needs and might also allow the farmer to negotiate his deliveries according to his plowing and planting schedules. Data on the costs of modifying existing installations to burn crop residues are scarce. Most studies have relied on modifications costs for retrofitting existing boilers to burn municipal solid waste (MSW). Crop residues do not require the large capital investment in classificiation equipment to separate metals and glass; however, dirt and rocks pose a problem.

This section contains descriptions and costs of processing and handling equipment for crop residues. Storage for 90 days is included in the capital and operations costs estimates. Costs for modifying an existing installation include sitework, buildings, equipment, rolling stock, engineering and contingency, and a conveying system to feed residues to the boiler. Estimates of the value in reducing sulfur emissions are reported from other studies.* None of the studies we examined accounted for the value of residue ash, or the cost savings of reduced ash disposal.

\subsection{UTILTY MODIFICATIONS COSTS}

Handling systems for large quantities of agricultural crop residue are necessary for utility applications. For short distances, conveying systems are the most practical. Conveying systems include the following types: drag, flight, belt, pneumatic, screw, and vibrating conveyors. Each of these may be modified easily to handle crop residues, but size reduction equipment may be required.

Other types of handling equipment include tote boxes, front-end loaders, and selfdumping trucks. Tote boxes are used for collection and transportation when handling requirements do not justify installing a conveying system. Front-end loaders and selfdumping trucks are used in many wood mills for transporting wood wastes over short distances (Towne 1976, p. 42). Several types of truck-trailers are available with a conveyor in the bottom that transports materials out the back without dumping.

Truck-trailers have been specially designed for transporting wood residue over public highways. For large distances, railcar hauling may be more cost competitive. Barges are used extensively in the Pacific Northwest for waste wood handling. A barge will haul

\footnotetext{
*Starr et al. (1978, p. 366) did not report modification costs because "the uniqueness of each boiler installation foiled an attempt to categorize the units on a needed modifications basis within the time frame. . . Modifications could run from virtually zero in a cyclone type boiler to very high costs associated with cutting into the side, sealing some water pipes, setting up controls, etc., in other types of boilers."
} 
$120,000 \mathrm{ft}^{3}$ of material compared to $7,000 \mathrm{ft}^{3}$ in a railcar and $3,000 \mathrm{ft}^{3}$ in a large tractor-trailer (Towne 1976 , p. 43). Most of these transport and handling systems can be applied to agricultural crop residues, with few modifications.

Each type of hauling system requires unloading facilities at the plant where they will be used. In addition to the self-dumping trailers already discussed, some installations have found it necessary to put in hydraulically tilted platforms or rollover dumpers to reduce loading and unloading times. Hydraulically tilted platforms are available to handle trailers, trucks and trailers, and railcars. Rollover dumpers literally roll a railcar upside down, emptying the contents into a hopper. Front-end loaders are typically used for small volumes.

A pneumatic system is also available which incorporates a digger head and suction nozzle to unload open top railcars. The digger head is designed to break up frozen chunks to a size suitable for handling in a pneumatis system. Barge unloading facilities include moorage and a winch system to move the barges under the loading chute. Barges do not appear to be a likely alternative for transporting residues in the near future.

Handling systems include sitework, buildings, equipment, rolling stock (front-end loaders) engineering and contingency, and primary conveying systems to move residues from storage to the boiler. Capital costs for these subsystems are presented in Table 3-1 and shown for different capacities expressed in tons/day. Estimates by Abdallah and Hitzhusen are compared with estimates by Short et al. The only level of stover throughput estimated by both studies is the 100 tons/day level. Abdallah omits charges for sitework and estimates for buildings are $\$ 150,000$ less than estimates by Short et al. Abdallah's estimates for rolling stock are almost one-third those of Short.

Both studies show remarkable declines in the cost per ton/day capacity as throughput increases. Capital costs per ton/day capacity decrease by half, increasing throughput from 50-150 tons/day in the estimates by Abdallah and Hitzhusen. Similar reductions are shown by Short et al. in going from 100-300 tons/day of throughput. In general, these estimates show that tripling throughput decreases capital costs per ton/day of capacity by half. Detailed modifications costs for the Ames, Iowa, generating station are presented in Appendix C, Tables C-4 and C-5.

Capital, operations and maintenance, and labor costs are presented in Table 3-2 for capacities ranging from 100-1,200 tons of throughput per day. Estimates by Short et al. range from a high of $\$ 12.66$ per ton for 100 tons of throughput per day to $\$ 3.22$ per ton for 1,200 tons of throughput per day. Estimates by Abdallah and Hitzhusen reflect the lower capital expenses but are presented only for 100 and 150 tons/day of throughput. Cost estimates were $\$ 3.66$ per ton for 100 tons/day and $\$ 3.01$ per ton for 150 tons/day of throughput. The average cost of systems reported by Starr et al. were about $\$ 4.00$ per ton. Abdallah and Hitzhusen neither report nor mention any labor charges for crop residue handling at the utility.

Assuming the on-farm harvesting costs are $\$ 16.93 /$ ton, transportation charges are $\$ 2.50 /$ ton, and $\$ 10 /$ ton is the farmer's profit, delivered costs of crop residue are $\$ 29.43 /$ ton or $\$ 2.03 / \mathrm{MBtu}$. Adding processing equipment capital charges, operation and maintenance expenses, and labor costs (Table 3-2), the costs of residue to the boiler range from $\$ 42.09 /$ ton (100 tons of throughput daily) or $\$ 2.90 / \mathrm{MBtu}$ to $\$ 33.06 /$ ton (900 tons of throughput daily) or $\$ 2.28 / \mathrm{MBtu}$. At $\$ 25.00 /$ ton, coal is about half as expensive (24 MBtu/ton) as crop residue. Coal prices, therefore, need to double before crop residue becomes a competitive fuel. 
Table 3-1. CAPITAL COSTS FOR PROCESSING AND HANDLING CROP RESIDUES IN STOKER-BOILER UTHITY APPLICATIONS

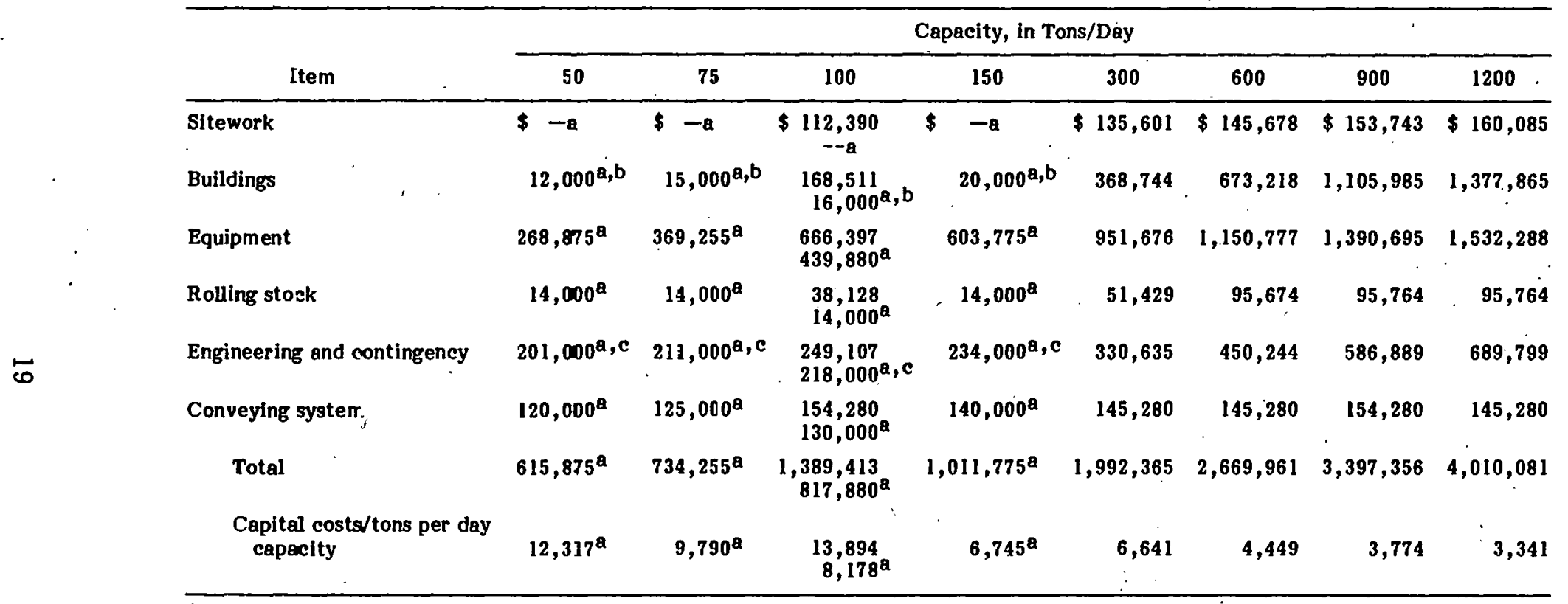

Abdallah and Hithusen 1975. See also Appendix C, Tables C-1 and C-2. All other estimates are by Short et al. 1978.

b Abdallah and Hitzhusen include the cost of a receiving noor.

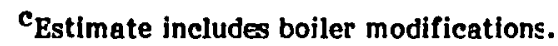


Table 3-2. CAPITAL, OPERATIONS AND MAINTENANCE, AND LABOR COSTS IN STOKER-BOILER UTHITY APPLICATIONS ( $\$ /$ ton)

\begin{tabular}{lrrrrrr}
\hline & \multicolumn{5}{c}{ Capacity, in Tons/Day } \\
\cline { 2 - 7 } & \multicolumn{1}{c}{100} & \multicolumn{1}{c}{150} & 300 & 600 & 900 & 1200 \\
\hline Capital Charges & $\$ 7.00$ & $\$ 1.83^{\mathrm{a}}$ & $\$ 3.33$ & $\$ 2.30$ & $\$ 1.85$ & $\$ 1.63$ \\
Operators and Maintenance & 3.02 & $1.18^{\mathrm{a}}$ & 1.86 & 1.44 & 1.30 & 1.23 \\
Labor & 2.64 & & .92 & .64 & .48 & .36 \\
$\quad$ Total & 12.66 & $3.01^{\mathrm{a}}$ & 6.11 & 4.28 & 3.63 & 3.22 \\
& $3.66^{\mathrm{a}}$ & & & & &
\end{tabular}

a Abdallah and Hitzhusen 1979 , p. 10 , converted from $\$ M B t u$ to $\$ /$ ton by their assumption of $13 \mathrm{MBtu} / \mathrm{T}$. All other estimates by Short et al. 1978. Costs for large round bale system are calculated with a discount rate of $9 \%$. No labor costs or requirements are mentioned or identified. Capital changes are separated from O\&M in Abdallah 1978, p. 91.

${ }^{b}$ Average cost/ton for systems reported in Starr et al. 1978. 


\section{SECTION 4.0}

\section{SUMMARY AND CONCLUSIONS}

This report examines the economic feasibility of burning crop residues for on-farm grain drying, grain drying at a grain elevator, and electricity generation at a utility. Table 4-1 presents cost summaries for these three direct combustion applications. The feasibility of using crop residues depends primarily on the costs of alternative fuels.

Following dramatic price increases for petroleum during 1979, grain drying is the most economically attractive alternative studied. For on-farm applications, a typical 400acre grain harvest would consume nearly 4,000 gallons of propane to dry 52,000 bushels of corn from 22\% moisture content wet basis (MCWB) to $15 \%$ MCWB. At $\$ 0.65$ per gallon, this amounts to about $\$ 2,600.00$. The same amount of heat obtained from crop residues would cost about $\$ 525$ for 30 tons of residue. The fuel savings, therefore, from using crop residue instead of propane amount to about $\$ 2,080$ for a typical 8-day harvest. These fuel savings are about $40 \%$ of the cost of the residue burner which is $\$ 5,500$ more than the cost of a similar propane-fired system with equivalent capacities. The onfarm grain dryers studied are mobile and could be used at several farms depending on the timing of harvest. Residue burners may also be used to heat farrowing houses and machine sheds.

Since one elevator services a large number of customers, the front-end capital costs of a residue burner can be spread over a larger harvest. A harvest of 700,000 bushels would require about 63,200 gallons of propane to dry corn from $23 \% \mathrm{MCWB}$ to $15 \% \mathrm{MCWB}$ for a total fuel cost of $\$ 41,100$. This drying requirement amounts to 468 tons of residue, which would cost about $\$ 13,700$. The fuel savings over propane amount to nearly $\$ 27,400$ per year-nearly the same cost as the drying equipment (bin excluded).

As noted in Sec. 3.0, the costs of using crop residues in utility applications are prohibitive if the current average cost of coal for utilities is used for comparison. Prices near $\$ 50 /$ ton are required for crop residues to be competitive. Most studies attempt to measure the cost savings of blending coal with crop residue to meet emissions standards for sulfur without installing pollution-control equipment. These studies ignore the addiliomul environmental costs incurred with coal mining: land reclamation, water pollution, black lung disease, and mining-related deaths. Solid fuels from biomass have many advantages from an environmental perspective. Although particulate emissions can be a problem, biomass has low sulfur content (see Appendix Table C-2). Sulfur is generally more expensive to remove from exhaust gases than particulates. The sulfur content of most biomass is about .1\% by weight, and low-sulfur western coal about $2 \%-20$ times greater than biomass by weight (.13 lb sulfur/MBtu for biomass; $1.6 \mathrm{lb}$ sulfur/MBtu for low sulfur western coal). Further, ashes from biomass fuels by direct combustion have nutritive value as fertilizer. Ashes from coal are a disposal problem and most are land filled. Biomass fuels are about $3 \%$ ash by weight or less while coal can be as much as $10 \%$ ash by weight. One million Btu of coal will generate $8.3 \mathrm{lb}$ of ash, compared with 4 $\mathrm{lb}$ of ash from crop residues. Biomass fuels do not contribute to net atmospheric $\mathrm{CO}_{2}$ concentrations if the land harvested for biomass fuels is revegetated.

Crop residues are a viable alternative to coal as a boiler fuel, if the prices of new contracts for coal are compared with the current costs of crop residues and all environmental costs are included in the calculations. 
Direct combustion of crop residues is an immediate alternative to conventional fuels for grain drying. Ignoring labor costs and incidental operations expenses, the fuel savings from residue-fired on-farm grain equal total capital costs about every 24 days of operation, assuming 6,500 bu of corn are dried daily from $22 \% \mathrm{MCWB}$ to $15 \% \mathrm{MCWB}$, and the only drying alternative is propane. In addition, on-farm residue burners are mobile and can dry other farmers' crops or be used for space heating farrowing houses and machine sheds. Residue-fired grain dryers placed in grain elevator applications offer the largest savings, which could conceivably be 10 times greater than the cost of the residue burner alone in every year of operation. The potential use of crop residues as a utility boiler fuel depends on the specific characteristics of each boiler application as well as on the accessibility and cost of coal. 
Table 4-1. COST SUMMARIES FOR CROP RESIDUE DIRECT COMBUSTION APPLICATIONS

\begin{tabular}{|c|c|c|c|c|c|c|}
\hline \multirow[b]{3}{*}{$\begin{array}{l}\text { Harvesting and On-Farm } \\
\text { Transport Costs } \$ / \text { ton }^{a}\end{array}$} & \multirow{2}{*}{$\begin{array}{l}\text { On-farm } \\
\text { Grain Dryers }\end{array}$} & \multirow{2}{*}{$\begin{array}{l}\text { Grain Elevator } \\
\text { Grain Dryers }\end{array}$} & \multicolumn{4}{|c|}{$\begin{array}{l}\text { Stoker-Boiler Utility Applications } \\
\text { in Tọs/Day }\end{array}$} \\
\hline & & & 100 & 300 & \multicolumn{2}{|c|}{900} \\
\hline & 16.93 & 16.93 & 16.93 & 16.93 & $\$$ & 16.93 \\
\hline Capital Costs & $25,000.00$ & $28,000.00$ & $1,389,413.00$ & $1,992,365.00$ & & ,356.00 \\
\hline Transportation Charges $\$ /$ ton-mile & & 0.25 & .025 & .025 & & .025 \\
\hline Capital Charges $\$ /$ ton & & & 7.00 & 3.33 & & 1.85 \\
\hline $\begin{array}{l}\text { Operations and Maintenance } \\
\text { Charges } \$ / \text { ton }\end{array}$ & & & 3.02 & 1.86 & & 1.30 \\
\hline Labcr $\$ /$ toa & & & 2.64 & 0.92 & & 0.48 \\
\hline Profit on Residues $\$ /$ ton & & 10.00 & 10.00 & 10.00 & & 10.00 \\
\hline $\begin{array}{l}\text { Total Cost of Residues at } \\
\text { sile used } \$ / \text { ton } \\
\$ / \mathrm{MBtu}(14.5 \mathrm{MBtu} / \text { ton) }\end{array}$ & $\begin{array}{r}16.93 \\
1.17\end{array}$ & $\begin{array}{r}29.43 \\
2.03\end{array}$ & $\begin{array}{r}42.09 \\
2.90\end{array}$ & $\begin{array}{r}35.54 \\
2.45\end{array}$ & & $\begin{array}{r}33.06 \\
2.28\end{array}$ \\
\hline Crecit for Sulfur Emissions \$/MBtu & & & 0.30 & 0.30 & & 0.30 \\
\hline $\begin{array}{l}\text { Cost of Conventional Puel Alternative } \\
\text { Propane } \$ 0.65 / \mathrm{gal} \$ \mathrm{MBtu} \\
\text { Coal } \$ \mathrm{MBtu}\end{array}$ & 7.14 & 7.14 & & & & \\
\hline $\begin{array}{l}(\$ 25 / \text { ton and } 24 \mathrm{MBtu} / \mathrm{ton}) \\
\$ 50 / \text { ton and } 24 \mathrm{MBtu} / \mathrm{ton})\end{array}$ & & & $\begin{array}{l}1.04 \\
2.08\end{array}$ & $\begin{array}{l}1.04 \\
2.08\end{array}$ & & $\begin{array}{l}1.04 \\
2.08\end{array}$ \\
\hline
\end{tabular}

$\mathbf{a}_{\text {All costs and assumptions are explained in Section 4.0. }}$ 


$$
\text { SERI }
$$




\section{SECTION 5.0}

\section{REPERENCES AND BIBLIOGRAPHY}

Abdallah, M. H. 1978. "Economics of Corn Stover as a Coal Supplement in SteamElectric Power Plants in the North Central United States." Unpublished Ph.D. Dissertation, Ohio State University.

American Society of Agricultural Engineers. 1973. "Agricultural Machinery Management Data." Agricultural Engineering Yearbook; pp. 314-321.

Ayres, G. E. "An Evaluation of Machinery Systems for Harvesting the Total Corn Plant." Unpublished Ph.D. Dissertation, Iowa State University. University Microfilms Order no. 74-9101.

Ayres, G. E.; and Buchele, W. F. 1976. "An Evaluation of Machinery Systems for Harvesting the Total Corn Plant." American Society of Agricultural Engineers, Paper No. 76-1015.

Beneman, J. R. "Biofuels: A Survey." ER-746-SR. Palo Alto, CA: Electric Power Research Institute.

Bhagat, N.; Davitian, H.; and Pouder, R. 1979. "The Potential of Crop Residues as a Fuel for Power Generation." Brookhaven National Laboratory Report No. 50982, Upton, N.Y.: July.

Brockhous, D. Fremont, NB: Stormor, Inc.

Brooker, D. B.; Bakker-Arkema, F. W.; and Hall, C. W. 1974. Drying Cereal Grains. Westport, CT: AVI Publishing Company, Inc.

Brown, O. D. 1977. "Energy Generation from Wood-Waste." Presented at Governor W. G. Milliken's Conference on Wood Energy. University of Michigan; November.

Buchele, W. F.; and Marley, S. J. 1978. "Energy Production from Crop Residue." Meetings of the Soil Conservation Suciety. Denver, CO: July 30-August 2.

Center for Energy Studies. 1977. "Use of Crop Residue to Support a Municipal Electric Utility." CES No. 41. Kansas State University; June.

Council of Forest Industries of British Columbia. 1976. "Pollution Control Practices in the Forest Products Industry." Unpublished Monograph presented at a meeting of Public Inquiry on Pollution Control Objectives of the Forest Products Industry; March.

Dauve, J. Golden, CO: Solar Energy Research Instltute.

Dauve, J.; Flaim, S. J. 1979. "Agricultural Crop Residue Collection Costs." Report No. RR-353-354. Golden, CO: Solar Energy Research Institute; December.

"Deep Layer Bottom Unload Drying versus Continuous or Batch Drying." Unpublished essay. Columbus, NB: Middle State Manufacturing, Ine. 
Doane's Agricultural Report. 1979. St. Louis, MO: Doane's Agricultural Service; p. 354.3.

Doane's. $1979 ;$ p. 358.4 .

"The Economies of Using Crop Residue to Dry Grain." Sales leaflet. Fremont, NB: Stormor, Inc.

English, B. C.; Short, C. C.; and Heady, E. O. 1979. "An Economic Feasibility Study of Crop Residues as an Auxiliary Power Source for Iowa's Coal-Fired Power Plants." Meetings of the American Agricultural Economics Association. Pullman, WA: July 29August 1 .

Finn-Carlson, D. W.; and Starr, P. J. 1978. "A Regional Model to Assess Alternate Systems for Conversion of Crop Residues to Energy." Presented at Energy Systems International Symposium, Montreal, Canada; June 1-2.

Flaim, S, 1979. "Soil Fertility and Soil Loss Constraints on Crop Residue Removal for Energy Production." Report No. RR-52-324. Golden, CO: Solar Ënergy Research Institute; July.

Forest Products Research Society. 1976. "Wood Residue as an Energy Source." Proceedings of an FPRS Workshop, Denver, Colorado; September 3-5.

Handbook of Chemistry and Physics. 1951. 33rd Edition. Cleveland, OH: Chemical Rubber Publishing Company; p. 1595.

Hitzhusen, F.; Shenk, R.; and Rivet, R. 1979. "Economics of Nonmetropolitan Solid Waste Resource Recovery in the North Central Region." North Central Regionul Centel" for Rural Development, Iowa State University; No. 50011; February.

Horsfield, B. C.; Becker, C.; and Jenkins, B. 1977. "Agricultural Residues as an Alternative Source of Energy for the Pacific Gas and Electric Company." Research Report of the Department of Agricultural Engineering, University of California, Davis; July.

Joseph, G. L. 1979. Columbus, NB: Middle State Manufacturing, Inc.

Junge, D. C. 1975. "Boilers Fired with Wood and Bark Residues." Research Bulletin 17. Forest Research Laboratory, Oregon State University; November.

. 1977. "Investigation of the Rate of Combustion of Wood Residue Fuel." Technical Progress Report No. 1, Oregon State University. September.

Kajewski, A. H. 1977. "Design and Development of a Biomass-Fired Grain Dryer." Unpublished Master's Thesis, Department of Agricultural Engineering, Iowa State University.

Koelsch, R. K.; Clark, S. J.; Larson, W. E. 1977. Straw Collection and Delivery Systems for a Municipal Electric Generating Station. CES, No. 30. Manhatten, KS: Engineering Experiment Station, Kansas State University; January.

B. H. Levelton and Associates Ltd. 1978. "An Evaluation of Wood-Waste Energy Conversion Systems." Unpublished monograph. Vancouver, B.C.: B. H. Levelton and Associates Ltd.; March. 
Lockeretz, W., ed. 1977. Agriculture and Energy. N.Y., N.Y.: Academic Press.

McManama, G. P. 1979. Seattle, WA: Wyatt Engineers, Inc.

Mathews Company. 1979. Sales catalog. Crystal Lake, IL.

Middle State Manufacturing, Inc. Columbus, NB.

Miles, T., Jr. Portland, OR: Thomas R. Miles, Consulting Engineer.

Miles, T. R. 1978. "Btu's by the Bale." Presented at the Pacific Northwest Bioconversion Workshop. Portland, OR: October 24-26.

- 1979. "Biomass in the Northwest-Available Inventory." Presented at the Solar

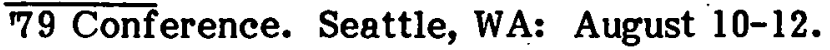

The National Climatic Data Center. Asheville, N.C.: based on temperature data for Dubuque, Iowa.

Nor'West Pacific Corp. 1979. "Wood Fuel-Fired Electric Power Generating Plants." Springfield, VA: NTIS: TID-28963.

Oursbourn, C. D.; et al. 1978. "Energy Potential of Texas Crops and Agricultural Residues." MP-1361. Center for Energy and Mineral Resources, The Texas Agricultural Experiment Station. College Station, TX: February.

Reed, T. and Bryant, B. 1978. "Densified Biomass: A New Form of Solid Fuel." SERI35. Golden, CO: Solar Energy Research Institute; July.

Reese, R. G. 1976. "The Application of a Dry Scrubber to Waste Wood-Fired Boilers and Its Benefits." Wood Residue as an Energy Source. Proceedings of a Forest Products Research Society Workshop. Denver, CO: September 3-5; pp. 66-69.

Report of the First World Straw Conference. 1975. Eugene, OR: May.

Short, C.; et al. 1978. "The Cost of Crop Residúes as an Auxiliary Fuel Source for CoalFired Power Plants." Proceedings: Fif th Annual UMR-DNR Conference and Exposition on Energy. Rolla, MO: October 10-12.

Starr, P. J.; Finn-Carlson, D. W.; and Nachtsheim, C. 1978. "Crop Residues as Energy Sources: Assessing the Cost and Energy Feasibility of Direct Firing." Energy Sources. Vol. 3, No. 3/4; May.

Stanford, G. 1979. Cedar Hill, TX: Director, Greenhills Center.

Stormor, Inc. Fremont, NB.

Towne, R. S. 1976. "Wood Waste Handling Trends." Wood Residue as an Energy Source. Proceedings of a Forest Products Research Society Workshop. Denver, CO: September 3-5; pp. 42-45.

Walters, D. F. 1976. "Air Quality Regulations Affecting the Use of Wood Residuce as a Fuel." In Wood Residue as an Energy Source. Proceedings of a Forest Products Research Society Workshop. Denver, CO: September 3-5; pp. 4-7. 
White, W. C., and Collins, D..N., eds. 1976. The Fertilizer Handbook. Washington, D.C.: The Fertilizer Institute.

Workman, H. E. 1975. Estimating Farm Custom Work Costs. Columbia, MO: Cooperative Extension Service, University of Missouri; March. 


\section{APPENDIX A}

\section{PRINCIPLES OF COMBUSTION}

When crop residues are burned, a complex process called combustion takes place. Combustion includes both physical and chemical reactions, and is both an oxidation and reduction process. Fuel is oxidized by oxygen from the air and oxygen in the air is reduced by the components of the fuel. Oxygen from the air is necessary for burning; the burning rate can be controlled by the concentration of available oxygen. Pure oxygen will consume fuels at a much higher rate than normal air, but pure oxygen is seldom used with residue fuel boilers except where primary or secondary air is recirculated.from a combustion-exhaust system (Junge 1975, p. 11).

Combustion is an exothermic process that releases or emits heat. The amount of heat emitted as a fuel is burned can be determined. The amount of heat released from burning wheat straw is about $7,500 \mathrm{Btu} / \mathrm{lb}$ (lower heating value) at $12 \%$ moisture content wet basis (MCWB) (Miles 1979, p. 1).

Combustion rates are determined by temperature, pressure, availability of reactants (fuels and air), and the reaction mechanism itself. Of these, the first three can be controlled. Temperature and the availability of reactants can be controlled through air and fuel feed rates and furnace design. Pressure, while controllable, for practical reasons is not a subject of interest in most residue combustion applications. If the other factors are fixed, the rate of the chemical reaction mechanism is determined, for a specific fuel. An example of differences in oxidation rates would be those of carbon and iron in a furnace under the same conditions. The carbon would burn fairly rapidly, while the iron would exhibit very little oxidation.

Fuels can be solids, liquids, or gases. Most fuels will combust only in their gaseous form, except for carbon which can burn as a solid (although much of it burns after being gasified into carbon monoxide). In the combustion of solid fuels, materials are heated to a temperature high enough to drive off the water in the fuel as water vapor, to cause the fuel to decompose, and the volatile component of the fuel to evaporate. The remaining carbon either burns in its solid phase or reacts with air to form carbon monoxide, which, with the volatile components, mixes thoroughly with oxygen in the air so the mixture burns. A thorough mixing of fuel and oxygen and adequate residence time increase the combustion efficiency of the furnace and reduce the quantity of unburned hydrocarbons emitted as pollutants.

Combustion of solid fuels occurs in the following steps:

- Dehydration, a physical process, occurs first. Fuel is heated to the point where water evaporates.

- Evaporation, also a physical process, occurs second. The volatile components of the material are heated until they change from the solid to gaseous phase.

- Pyrolysis occurs next. Pyrolysis is a chemical decomposition of the original molecules into smaller molecular species because of high temperatures.

- Mixing, a physical process, occurs fourth, as the fuel is evaporated and comes into contact with combustion air.

- Oxidation and reduction, a chemical reaction process, occurs when the fuel and air react to form new chemical substances and heat and light are emitted. 
To summarize, combustion is a complex physical and chemical reaction that takes place primarily in the gaseous phase.

Combustion can be idealized as two simple reactions. First, carbon (C) combines with oxygen $\left(\mathrm{O}_{2}\right)$ to form carbon dioxide $\left(\mathrm{CO}_{2}\right)$. Second, hydrogen $(\mathrm{H})$ combines with $\mathrm{O}_{2}$ to for $\mathrm{m}$ water $\left(\mathrm{H}_{2} \mathrm{O}\right)$. These basic chemical reactions can be used to determine how much oxygen is required to bring the reactions to completion. The exact amount of air required to burn 100 pounds of residue fuel can be determined by stoichiometric calculations.* Although the exact amount of air required to burn a given quantity of a fuel can be determined, some excess air is required for actual practices for two reasons. First, for complete combustion, each molecule of gaseous fuel must come into contact with one or more molecules of oxygen. To ensure this mixing, extra molecules of oxygen must be supplied to increase the probability that the fuel molecules contact oxygen molecules. Second, some furnace designs require excess air to assist in drying wet fuel and to distribute the fuel evenly on the furnace grates. The amount of excess air used plus the materials in the fuel determine the products of combustion and the constituents of the flue gases.

The major factors that affect the combustion of residue fuels may be separated into two groups: fuel-related and air-related factors. The most important fuel-related factors are fuel size, moisture content, method of feeding fuel, and feeding rates. Because oxidation occurs primarily in the gaseous phase, proper conditions for evaporation of the fuel are required. The size of the fuel particles directly affects their ability to evaporate. Large pieces tend to insulate their interior parts, which requires more time for the volatile material to evaporate.** Moisture content directly affects the rate at which fuel can evaporate to the gaseous state. The first step in the combustion process, evaporation of water, is required before the fuel will volatilize. If the moisture content is high, this process takes considerable time and energy. If the moisture content is highly variable, controlling the combustion process is very difficult. Increasing the moisture content of fuel increases heat losses and thereby reduces overall efficiency. In addition, increasing the moisture content retards combustion, lowers flame temperatures, and reduces the rate at which heat is emitted (Junge 1975, p. 21).

The method of feeding fuel and feeding rates are important determinants of combustion efficiency. Most fuel-feed systems are controlled on a bulk-volume basis; i.e., they are designed to vary only the volumetric flow rate of the fuel. These fuel-feed systems cannot measure the moisture, size, and Btu content of the fuels fed. This increases the

*Stoichiometry refers to the calculation of reactants and products involved in a chemical reaction. For combustion calculations, the pound mole is a useful unit. A pound mole of a substance is the same as the molecular weight of that substance, expressed in pounds. For example, a pound mole of carbon is $12 \mathrm{lb}$ of carbon. The pound mole unit has two important features. First, when chemicals undergo chemical reactions, the proportions of the materials are usually expressed in pound moles. For example, when carbon combines with oxygen to form carbon dioxide, $12 \mathrm{lb}$ of carbon combine with $32 \mathrm{lb}$ of oxygen to form $44 \mathrm{lb}$ of carbon dioxide. The second feature of pound moles is that, for gases, a pound mole always takes up the same volume under standard conditions of temperature and pressure. This information helps to determine the volume of oxygen required to burn a specific weight of residue fuel, and the volume of air required to obtain the oxygen.

**Nor'West Pacific Corp. (1979) reported that 64 of the 68 wood electric systems they surveyed use size reduction equipment to reduce particle size variability. 
difficulty of controlling combustion to meet emissions standards and load requirements. The Eugene Water and Electric Board, which burns hogged wood fuel for electricity and steam sales, often wets its fuel in storage to attain near uniform but high moisture content fuel for more accurate control of its steam generators and to control dust (Brown 1977).

Air-related combustion factors include the percentage of excess air, air temperature, and air turbulence. Some excess air is required to combust residue fuels properly. However, too much excess air can be detrimental because the combustion temperature is reduced and the rate of reaction is slowed. In addition, thermal efficiency is reduced, gas velocities increase, the residence time of gases is reduced, a loss of combustion control follows, and emissions increase. Air temperature has a substantial effect on combustion. Preheating air increases its ability to remove moisture from wet fuel, and increases the furnace temperature (which increases the rate of combustion and reduces the formation of air pollutants). Increased air turbulence increases the mixing of fuel gases and oxygen. Generally, the greater the turbulence, the higher the probability that the fuel will burn completely. Mixing is important to avoid dead spaces where fuel vapors can accumulate and reach high concentrations, which can result in explosions.

Because combustion is a complex process and the moisture content and size of residue fuels may vary widely, most furnaces have fuel and air-related controls. Four fuelrelated combustion controls are commonly used in large residue-fired furnaces and boilers: size, moisture content, storage, and fuel feeding controls. Four systems are typically used to control fuel size: screening devices, hammer hogs for particle size reduction, mixing units, and separate storage facilities for different residues. Moisture content controls typically used are shaker screens, mechanical presses, dryers, and management practices to limit the amount of moisture absorbed by the fuel while in storage. Storage practices are important for controlling size and moisture content in residue fuels. Fuel-feed controls distribute the fuel within the furnace, and vary fuel feed rates to match loads and the combustion characteristics of the fuel.

Air controls limit the percentage of excess air, air temperature, and air turbulence to control combustion. Many air-related variables affect the efficiency of combustion; the influence of each is not separable. Excess air can be controlled easily but the products of combustion must be monitored continuously. In most wood waste boilers, air temperature is not regulatcd dircetly and control of air temperature is not possible. Air turbulence is usually controlled by furnace design; however, baffels and dampers can be used to increase the gas retention time.

Particulate emissions and operating efficiencies of residue-fired burners are inversely related. Emissions increase when hydrocarbons escape without being burned. As noted, if theoretical optimum conditions of operation are met, pollution is not a problem. However, the moisture content, energy content, and particle size of residue fuels vary widely. Most waste fuel furnace and boiler manufacturers contacted by the authors have designed new equipment to operate over a wide range of conditions. However, most of this equipment is designed for large industrial processes. Since most combustion equipment now being used was in place at the time of regulation enactment, pollution-control objectives have been approached by simply adding pollution-control equipment at the exhaust stack. Appendix B outlines the "add-on" approach to pollution control. 


\section{SEP|}




\section{APPENDIX B}

\section{POLLUTION CONTROL REGULATTONS AND DEVICES}

Pollution control regulations are established by federal, state, local, and regional agencies. These agencies enforce their standards by a permit system which requires that any piece of machinery or process that generates pollutant materials to the atmosphere must have a permit to operate. Permits may be obtained after one demonstrates that the pollutant emissions will be lower than the maximum values established by the agencies. Agencies have set standards regarding opacity, concentration of particulate matter, size of particulate matter, nuisance from emissions of particulate matter, and sulfur dioxide (Walters 1976). A summary of pollution control implementation plans by states and U.S. possessions is presented in Table $3-1$.

Opacity standards are based on the age and location of an installation. In general, boilers that were installed and operating before 1970 and are located in areas of low population density are subject to the more liberal $40 \%$ limitation; new installations are subject to the $20 \%$ limitation by most agencies. The regulations specify that the opacity of the plume from the stack may not exceed a certain percent (the limitation) for a specific period of time (Junge 1975, p. 55).

Standards on concentration of particulate matter are often stated in terms of maximum grains per standard dry $\mathrm{ft}^{3}$ of exhaust gas corrected to $12 \%$ carbon dioxide. Regulatory agencies generally agree that a standard dry $\mathrm{ft}^{3}$ is defined at 1 atmosphere of pressure; standard temperatures are defined differently and range from $32^{\circ} \mathrm{F}$ to $70^{\circ} \mathrm{F}$. Most agencies have set either .10 or .20 grain $(1 / 7,000 \mathrm{lb})$ per standard dry $\mathrm{ft}^{3}$ as the maximum limit. The correction to $12 \%$ carbon dioxide is made to keep individual plants from meeting standards by diluting the stack gases with clean air (Junge 1975, p. 55).

Some agencies have established limits on the maximum permissible size of particles emitted by boilers, usually at 250 microns (Council of Forest Industries, p. 114). The purpose of such a regulation is to prevent spreading large pieces of unburned carbon, which can be a soiling nuisance. Other nuisance regulations are general statements to the effect that no process or machine shall emit materials that are a nuisance to the surrounding property or community. Sulfur content of emissions is limited to prevent formation of $\mathrm{SO}_{\mathrm{X}}$ compounds. Sulfur emissions for residue fuels are about one-tenth of the EPA standard for coal on an equivalent energy basis.

Pollution-control devices for residue furnaces include electrostatic precipitators, cyclones, baghouse filters, and scrubbers. Electrostatic precipitators operate by negatively charging particles in stack gases and then collecting the particles on a plate with a positive charge. Shaking devices dislodge particles and the particles fall into a collection hopper. Because carbon has low electrical resistivity, precipitators have not proven very effective in wood waste fuel applications (Council of Forest Industries, p. 113).

Cyclones are the most common particle separator. As stack gases are spun through the cyclone, particles collect on the walls and migrate downward to a collection hopper. Major factors that affect cyclone efficiency are: diameter and length of the cyclone, particle disengaging zones, flow rates of the stack gases, and particle characteristics (Junge 1975 , p. 47).

Baghouse filters are containers filled with bags made of cloth. Stack gases are filtered through the bags where particles are captured. These filters are expensive but very 
Table B-1. SUMMARY OF POLLUTION CONTROL IMPLEMENTATION PLANS FOR STATES AND U.S. POSSESSIONS IN $1976^{\mathrm{Q}}$

\begin{tabular}{lc}
\hline \multicolumn{1}{c}{ Control Regulation } & Number of States \\
\hline Particulate Matter Limitations & $54^{\mathrm{b}}$ \\
Fuel Combustion Sources & $54^{\mathrm{C}}$ \\
Incineration & 55 \\
Industrial Process & 55 \\
Visible Emissions & 13 \\
Kraft Pulp Mills & \\
Sulfur Dioxide Limitations & $54^{\mathrm{d}}$ \\
Fuel Combustion Souroos & 13 \\
Noil=Fer'rus Sillelter's & 36 \\
Sulfuric Acid Plants & 5 \\
Sulfite Pulp Mills & \\
Total Reduced Sulfur Limitations & 11 \\
Kraft Pulp Mills & 13 \\
Carbon Monoxide Limitations & \\
Nitrogen Oxide Limitations & 21 \\
$\quad$ Nitric Acid Plants & 31 \\
Hydrocarbon Limitations &
\end{tabular}

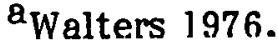

${ }^{b}$ All States and Possessions except Guam.

CAll states and Possessions except. 'I'exas.

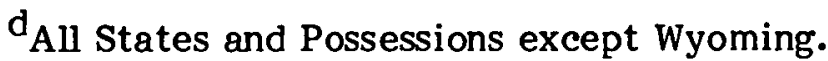


efficient. Disadvantages include bag wear, the large structure required, condensation problems in the bags, and substantial fire hazards.

Most scrubbers commercially available are wet scrubbers which are designed to wash particles out of the gas stream. Wash water is transferred to settling ponds or others for particle separation. Wet scrubbers are not subject to fire damage, but they have been criticized because they simply transform an air-pollution problem into a water-pollution problem. Dry scrubbers recirculate pea gravel through a container in which stack gases are passed (Reese 1976). The gravel continually flows downward until it passes out of the scrubber and onto a screen where particles are separated and collected. The main deterrent to dry scrubbers is the higher initial capital expense relative to other pollutioncontrol equipment.

The largest potential for improving the emissions of solid fuel furnaces may be in furnace design (McManama 1979). Many waste fuel furnaces in the forest industry preceded cheap fossil fuels and electricity. These furnaces served the double function of generating power and disposing waste, and little attention was paid to the levels of emissions from these units. "Some plants that have had wood burning boilers for a long time have of ten looked upon those wood burning boilers as incinerators. As a result they don't keep the equipment up the way it should be and they don't worry about their fuel requirements and steam losses" (Walters 1976, p. 14). A substantial portion of particulates could be - used within the furnace if the retention time of gases could be increased. Most companies conformed to new environmental restrictions of the 1960 s by adding on clean-up units of the types mentioned. Pretreatment of the fuels being burned could eliminate some of the particulate emissions problems by narrowing the range of efficient operation. In the opinion of several engineers, the largest barriers to the use of wood wastes in the forest industry are environmental restrictions.

Regulations concerning particulate emissions make the use of crop residues in direct combustion applications more complicated and more expensive than fossil fuels. Crop residue moisture and energy content vary widely, making complete combustion difficult even in the best of circumstances. However, regulations on sulfur oxide emissions make biomass fuels an attractive blending agent. Crop residues can be blended with coal to reduce the average sulfur content of utility boiler fuel. Biomass fuels have many advantages from an environmental perspective. Sulfur is generally much more expensive to remove from exhaust gases than particulates. Biomass fuels have much lower ash content, which reduces disposal problems. Further, biomass fuels do not contribute to net atmospheric $\mathrm{CO}_{2}$ concentrations if land harvested for biomass fuels is revegetated. 
S=Ply 
APPENDIX C

DATA TABLES FOR SELECTED

CROP RESIDUE FUELS AND

PROCESSING RQUIPMENT 
SÆPl慗 
iil

Table C-1. ENERGY VALUES FOR SELECTED SOLID AND LIQUID FUELS ${ }^{\mathrm{B}}$

\begin{tabular}{lcc}
\hline & $\begin{array}{c}\text { Moisture } \\
\text { Content } \\
\text { Wet Basis } \\
\%\end{array}$ & $\begin{array}{c}\text { Net }^{\mathrm{b}} \\
\text { Heat } \\
\text { Value }\end{array}$ \\
\hline Solid Fuels: & & Btu/lb \\
Sawmill Residue & 50 & 4,500 \\
Municipal Solid Waste & 40 & 5,000 \\
Coal & 10 & 11,000 \\
Cord Wood & 20 & 6,700 \\
Corn Stalks & 20 & 7,245 \\
Straw & 12 & 7,500 \\
Tomato Vines & 0 & 6,730 \\
Liquid Fuels & & $B t u / g a l$ \\
Diesel Fuel & & 140,000 \\
Gasoline & & 120,000 \\
Ethanol & & 77,000 \\
Methanol & & 57,100 \\
\hline
\end{tabular}

$a_{\text {Miles }} 1979$ and Horsfield et al. 1977.

${ }^{b}$ Combustion calculations use either a higher or a lower heating value, depending on whether the heat of vaporization is included in the reported value. For the lower or net heat of combustion, it is assumed that all products of combustion remain in the gaseous state; however, for the higher or gross heat of combustion, the water vapor formed during the combustion is condensed to the liquid state. All comparisons in this study are based on the lower heating value. 
Table C-2. PROPERTIES OF SELECTED WASTE PUEL.S ${ }^{\natural}$

\begin{tabular}{|c|c|c|c|c|c|c|c|c|c|c|c|c|c|c|c|}
\hline \multirow[b]{2}{*}{ Kind of fuel } & \multicolumn{8}{|c|}{ Average composition and calorifis value of crude fuel } & \multicolumn{6}{|c|}{$\begin{array}{l}\text { Average compesition and e } e \text { lorlfic value } \\
\text { of contustible matter }\end{array}$} & \multirow{2}{*}{$\begin{array}{c}\text { Volatile } \\
\text { content } \\
\text { of combus- } \\
\text { tible matter } \\
\underset{\%}{ }\end{array}$} \\
\hline & $\begin{array}{l}\mathbf{C} \\
\mathscr{x}\end{array}$ & $\begin{array}{l}H \\
\text { H }\end{array}$ & $\begin{array}{l}0 \\
x\end{array}$ & $\stackrel{N}{\mathbf{x}}$ & $\begin{array}{l}\mathbf{S} \\
\mathbf{\%}\end{array}$ & - Ash & $\begin{array}{l}\text { Moisture } \\
\%\end{array}$ & $\begin{array}{c}\text { Net calorific } \\
\text { value, } \\
\text { Btu/lb }\end{array}$ & $\begin{array}{l}\mathbf{C} \\
\mathbf{x}\end{array}$ & $\begin{array}{l}H \\
\mathscr{H}\end{array}$ & $\begin{array}{l}0 \\
\%\end{array}$ & $\stackrel{N}{*}$ & $\begin{array}{l}\mathbf{S} \\
\boldsymbol{*}\end{array}$ & $\begin{array}{c}\text { Gross calorific } \\
\text { value, } \\
\text { Btu/lb }\end{array}$ & \\
\hline $\begin{array}{l}\text { Wood waste } \\
\text { (shavings, } \\
\text { trimmings, } \\
\text { etc. }\end{array}$ & $\begin{array}{l}42.1 \\
34.6 \\
27.2\end{array}$ & $\begin{array}{l}5.0 \\
4.2 \\
3.3\end{array}$ & $\begin{array}{l}34.8 \\
28.7 \\
22.5\end{array}$ & $\begin{array}{l}0.5 \\
0.4 \\
0.3\end{array}$ & $\bar{z}$ & $\begin{array}{l}3.6 \\
2.1 \\
1.7\end{array}$ & $\begin{array}{l}15.0 \\
30.0 \\
45.0\end{array}$ & $\begin{array}{l}6360 \\
5060 \\
3760\end{array}$ & 51.0 & 6.1 & 42.3 & 0.6 & - & 8750 & $70-85$ \\
\hline $\begin{array}{l}\text { Tan bark } \\
\text { Sunflower }\end{array}$ & 16.3 & 1.9 & 13.0 & 0.3 & 0.1 & $\$ .4$ & 66.0 & 1875 & 51.7 & 5.9 & 41.3 & 0.9 & 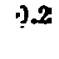 & 8700 & 76 \\
\hline $\begin{array}{l}\text { stalks } \\
\text { Flax stalks } \\
\text { Rice husks }\end{array}$ & $\begin{array}{l}48.0 \\
43.9 \\
35.9\end{array}$ & $\begin{array}{l}5.6 \\
5.3 \\
4.4\end{array}$ & $\begin{array}{l}39.5 \\
36.0 \\
30.6\end{array}$ & $\begin{array}{l}0.9 \\
0.9 \\
0.5\end{array}$ & $\begin{array}{l}0.1 \\
0.1 \\
0.1\end{array}$ & $\begin{array}{r}! .9 \\
=.8 \\
18.5\end{array}$ & $\begin{array}{r}4.0 \\
11.0 \\
10.0\end{array}$ & $\begin{array}{l}6740 \\
6930 \\
5640\end{array}$ & $\begin{array}{l}51.0 \\
51.0 \\
50.3\end{array}$ & $\begin{array}{l}5.9 \\
6.1 \\
6.1\end{array}$ & $\begin{array}{l}42.0 \\
41.8 \\
42.8\end{array}$ & $\begin{array}{l}1.0 \\
1.0 \\
0.7\end{array}$ & $\begin{array}{l}0.1 \\
0.1 \\
0.1\end{array}$ & $\begin{array}{l}8740 \\
8800 \\
8600\end{array}$ & $\begin{array}{l}80 \\
83 \\
80\end{array}$ \\
\hline Straw & 43.5 & 5.3 & 36.2 & 0.9 & 0.1 & 4.2 & 10.0 & 6650 & 50.5 & 6.2 & 42.2 & 1.0 & e.I & 8530 & \\
\hline
\end{tabular}

"Ordinanz, Wiliam D. "Cheracte:istics of Unusua' Waste Fuels." ?ower Generation. June 1949, p. 59. 
(1)

Table C-3. PROCESSING, STORAGE, AND CONVEYING COST ESTIMATES FOR UTILTYY BOILERS IN MINNESOTA ${ }^{a}$

\begin{tabular}{|c|c|}
\hline Item & Cost \\
\hline \multicolumn{2}{|l|}{$\begin{array}{l}\text { Processing } \\
\text { a) Tub Grinder ( } 220 \text { H.P.) } \\
\text { b) Blower ( } 80 \text { H.P. }) \\
\text { c) } 60 \text { H.P. Tractor }\end{array}$} \\
\hline Subtotal (.129 machine hrs/T@ \$10/hr. & $\$ 1.48^{b}$ \\
\hline $\begin{array}{l}\text { d) Labor }(.0722 \text { man hrs./T) } \\
\text { e) Fuel (1.202 gal./T Diesel @ .80/gal.) }\end{array}$ & $\begin{array}{l}.72 \\
.96\end{array}$ \\
\hline \multicolumn{2}{|l|}{$\begin{array}{l}\text { Storage - } 90 \text { day capacity } \\
\text { Ownership costs }\end{array}$} \\
\hline \multicolumn{2}{|l|}{$\begin{array}{l}\text { Conveying (.0033 machine hrs/T) } \\
\text { a) Ownership. costs (included w/storage above) } \\
\text { b) Fuel (.0016 gal./T Diesel @ .80/gal.) }\end{array}$} \\
\hline $\begin{array}{l}\text { Total } \$ 4.06 / \mathrm{T} \\
\quad \text { @ (16 MBtu/T and } 15 \% \text { M.C.W.B.) }\end{array}$ & $.25 / \mathrm{MBtu}$ \\
\hline \multicolumn{2}{|c|}{$\begin{array}{l}{ }^{\mathrm{a}} \text { Starr et al. } 1978 . \\
\text { b } \\
{ }^{\mathrm{b}} \text { Ownership costs include depreciation, fixed costs, and maintenance and } \\
\text { repair. Unit-of-production depreciation was used. Fixed costs include } \\
\text { interest, insurance, taxes, and machinery housing. Maintenance and } \\
\text { repair costs were calculated from American Society of Agricultural } \\
\text { Engineers } 1973 \text {. }\end{array}$} \\
\hline
\end{tabular}


Table C-4. CHARACTERISTICS OF THE AMES, IOWA, GENERATING STATION ${ }^{a}$

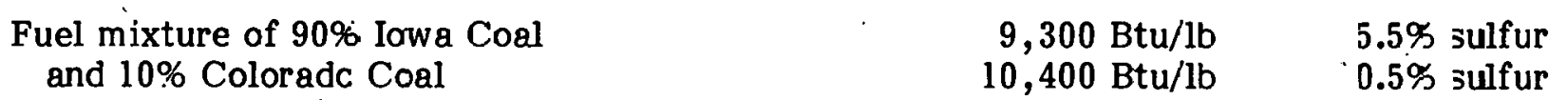

Cost of blend: $\$ 15 / \mathrm{million}$ Btu

Facility receives about 150 tons/day of municipgl solid waste from a population of 69,000 .

\begin{tabular}{|c|c|c|c|c|}
\hline Three Boilers & $\# 5$ & \#6 & $\exists 7$ & \#8 (not yet on line) \\
\hline $\begin{array}{l}\text { Type } \\
\text { Output } \\
\text { Firing Statistics }\end{array}$ & $\begin{array}{c}\text { Spreader Stoker } \\
8 \mathrm{MW} \\
7.6 \mathrm{~T} / \mathrm{hr} \text { coal only }\end{array}$ & $\begin{array}{c}\text { Spreader Stoker } \\
12 \mathrm{MW} \\
\cdot 10.0 \mathrm{~T} / \mathrm{hr} \text { coal only }\end{array}$ & $\begin{array}{c}\text { Pulve }-i z e d \text { Coal } \\
3 \mathrm{MH}_{\mathrm{e}} \\
22.7 \mathrm{~T} / \mathrm{hr} \text { coal } \\
8.7 \mathrm{~T} / \mathrm{hr} \mathrm{MSW}\end{array}$ & $\begin{array}{l}\text { Pulverized Coal } \\
65 \mathrm{MW}_{\mathrm{e}}\end{array}$ \\
\hline $\begin{array}{l}\text { Max. Firing Rate } \\
\text { Ash Handling } \\
\text { Stack Cleaning }\end{array}$ & $\begin{array}{c}50 \% \\
\text { Dry } \\
\text { Mechanical (cyclone) }\end{array}$ & $\begin{array}{c}50 \% \\
\text { Dry } \\
\text { Cyclone }\end{array}$ & $\begin{array}{c}20 \% \\
\text { Sluice } \\
\text { Electrostatic }\end{array}$ & $\begin{array}{c}20 \% \\
\text { Sluice } \\
\text { Electrostatic }\end{array}$ \\
\hline
\end{tabular}

a Typical output of facility is $30-40 \mathrm{MW}_{\mathrm{e}}$ witi an overall load factor of $45 \%$. Max:mum throughput of the shredder system is $50 \mathrm{~T} / \mathrm{hr}$. 
Table C-5. MODIPCATIONS REQUIRED TO BURN CROP RESIDUES IN THE AMES, IOWA, GENERATING STATION

MSW injection nozzles on all three boilers.

1973 dollars: 4 nozzles on \#7

2 each for \#5 and \#6

Extra air inlets on \# 5

Total cost: $\$ 176,000$

Stoker grate for \#7: $\$ 126,000$

Instrumentation of boilers, etc., was part of a 3.5 million contract for the MSW processing plant.

Storage bin: 600 tons storage.

Upper part of structure (base not included)

Controls

Cor - 10 top

Total Cost - $\$ 450,000$ 


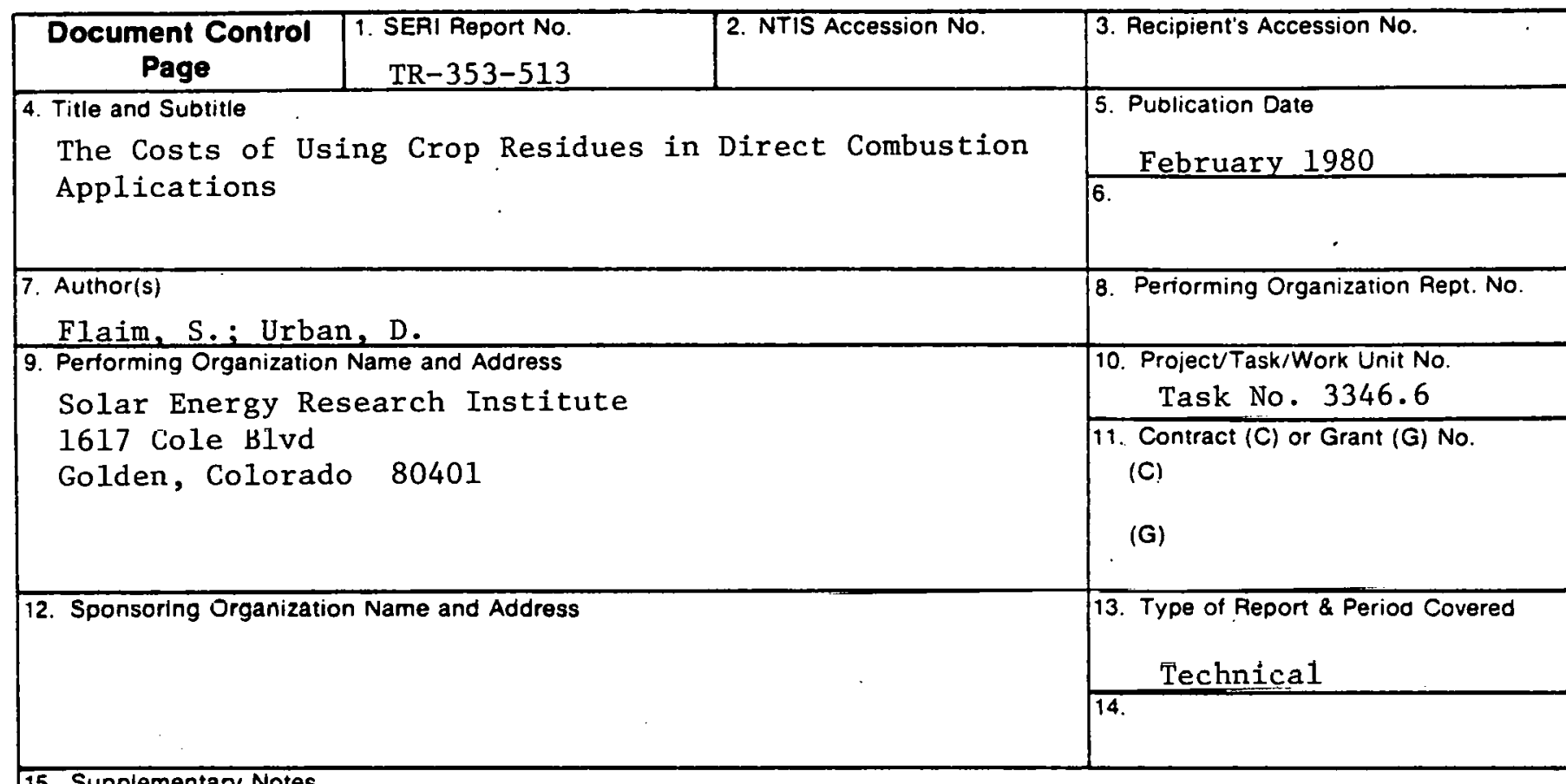

15. Supplementary Notes

16. Abstract (Limit: 200 words) This report examines the economic feasibility of burning crop residues for on-farm grain drying, grain drying at a grain elevator, and electricity generation at a utility. Following dramatic price increases for petroleum during 1979, grain drying is the most economically attractive alternative studied. For on-farm applications, a typical 400-acre grain harvest would consume nearly 5,500 gallons of propane to dry 52,000 bushels of corn from $22 \%$ moisture content wet basis (MCWB) to 15\% MCWB. Fuel savings from using crop residues instead of propane amount to nearly $\$ 2,080$ for a typical 8-day harvest. Since one grain elevator services many customers, the front-end capital costs of a residue burner can be spread over a larger harvest. The fuel savings over propane for grain elevators amount to nearl $\$ 27,400$ per year -- approximately the cost of the drying equipmont (bin creluded). 'The cost of using crop residues in utility applications are prohibitive if the average cost of coal for utilities is used for comparison. The potential use of crop residues as a utility boiler fuel is much greater than grain drying, but relative costs depend on the specific characteristics of each application and on the accessibility and cost of coal.

17. Document Analysis

a. Descriptors Combustion ; Crops ; Residues ; Cost ; Drying ; Aqriculture ; Transport ; Wheat ; Maize ; Cereals ;

b. Identifiers/Open-Ended Terms

c. UC Categories

$\mathrm{UC}-61$

${ }^{18}$ Navailability Statement

U.S. Department of Commerce

5285 Port Royal Road

Springfield, Virginia 22161

19. No. of Pages

52

20. Price

$\$ 5.25$ 